\title{
Multi-Attribute Analysis of Contemporary Cultural Buildings in the Historic Urban Fabric as Sustainable Spaces-Krakow Case Study
}

\author{
Ernestyna Szpakowska-Loranc
}

check for updates

Citation: Szpakowska-Loranc, E.

Multi-Attribute Analysis of

Contemporary Cultural Buildings in the Historic Urban Fabric as

Sustainable Spaces-Krakow Case

Study. Sustainability 2021, 13, 6126.

https://doi.org/10.3390/su13116126

Academic Editor: Tomonobu Senjyu

Received: 1 May 2021

Accepted: 24 May 2021

Published: 28 May 2021

Publisher's Note: MDPI stays neutral with regard to jurisdictional claims in published maps and institutional affiliations.

Copyright: (C) 2021 by the author. Licensee MDPI, Basel, Switzerland. This article is an open access article distributed under the terms and conditions of the Creative Commons Attribution (CC BY) license (https:/ / creativecommons.org/licenses/by/ $4.0 /)$.
Faculty of Architecture, Cracow University of Technology, 31-155 Krakow, Poland; eszpakowska@pk.edu.pl

\begin{abstract}
This study concerns contemporary cultural buildings in the historic city centre of Krakow, Poland, and their assessment in terms of sustainability. The paper aims to bridge a research gap in previous studies on pluralistic values and the impact of cultural heritage on sustainability. The comparative case study conducted in Krakow aims to evaluate the functioning and potential of the space towards achieving the following five goals: accessibility, conservation, mix of functions, aesthetics, comfort and sociability. The perception of these buildings and the public space around them by the city residents, as well as their operation during unexpected circumstances, such as the COVID-19 pandemic, were also evaluated. The author combined an on-site analysis, behavioural mapping and a survey. The results correlate the liveability and aesthetics of public spaces along with the amount and quality of greenery found there with the comfort of users and the popularity of particular places. This paper highlights how important it is to create cultural spaces in a historic city to develop a range of their activities linked to the surrounding public spaces and green areas. Activating cultural spaces and connecting them to sustainability goals is especially important when faced with declining tourism.
\end{abstract}

Keywords: sustainable development; cultural heritage; building heritage; inclusive space; COVID-19 urban planning; post-pandemic urban planning; Krakow

\section{Introduction}

Implementing high-budget engineering solutions for sustainability is not always possible for economic reasons. The countries of lower economic power are lagging behind in this race [1], which is also evident in Central and Eastern European countries when compared to their wealthier western neighbours [2,3]. Central and Eastern European countries are among those that still rely heavily on fossil fuels [4-6] and struggle with an adequate percentage of recycled rubbish [7] and small-scale water retention in built-up areas [8]. This does not mean that the SDGs (Sustainable Development Goals) are to be abandoned with no effort to achieve them. A certain degree of sustainability should be achieved through other methods and then it should be extended to include the measures mentioned above. Such measures can be found in the three pillars of sustainability [9].

The problem is exacerbated in the areas with historic structures, representing a significant percentage of the built-up area in Europe. This is evidenced by the $26.4 \%$ share of dwellings built before 1945 [10]. Being of indisputable historical, social, aesthetic and economic value, these heritage areas are worth protecting, but they also generate environmental problems due to their typology of traditional towns. Characterised by dense development and limited greenery, historic centres of large cities become urban heat islands [11], contributing to increased air pollution and other environmental pathologies [12]. The conversion of protected historic heritage into NZEBs (nearly zero-energy buildings) presents many difficulties [13]. Given the need to protect cultural values in these areas, measures of a different kind must be planned and implemented. These measures must include urban layout, buildings and public interiors. It is easier to introduce eco-friendly 
solutions where urban investments are concerned, as they are generally less driven by the desire for investment profit. When planned properly, public buildings, including cultural facilities and adjacent urban spaces, can both improve the ecology of a given space and increase its social value [14]. The areas in question are strongly affected by the phenomenon of gentrification, which was particularly evident in 2020. The decline in tourism during the COVID-19 pandemic demonstrated the lack of resilience in districts that proved to be mono-functional desolate spaces when deprived of foreign visitors [15]. The cultural sector in Krakow is facing a crisis, halting its programme activities and moving from the urban space to the Internet [16].

The research examines contemporary public buildings serving a cultural function in the historic urban fabric in the context of sustainable development and spatial inclusion (Figure 1). Central and Eastern European cities constitute a good field to analyse the situation of developing metropolises. Krakow, chosen as the research site, is among them. It is the second-largest Polish city whose number of tourist visitors has steadily increased over the past 10 years to $14,050,000$ in 2019, but dropping to 7,950,000 in 2020 due to the pandemic $[17,18]$. Although the city has SDG ideas embedded in its strategy [19], it does not introduce NZEB technologies in public buildings.

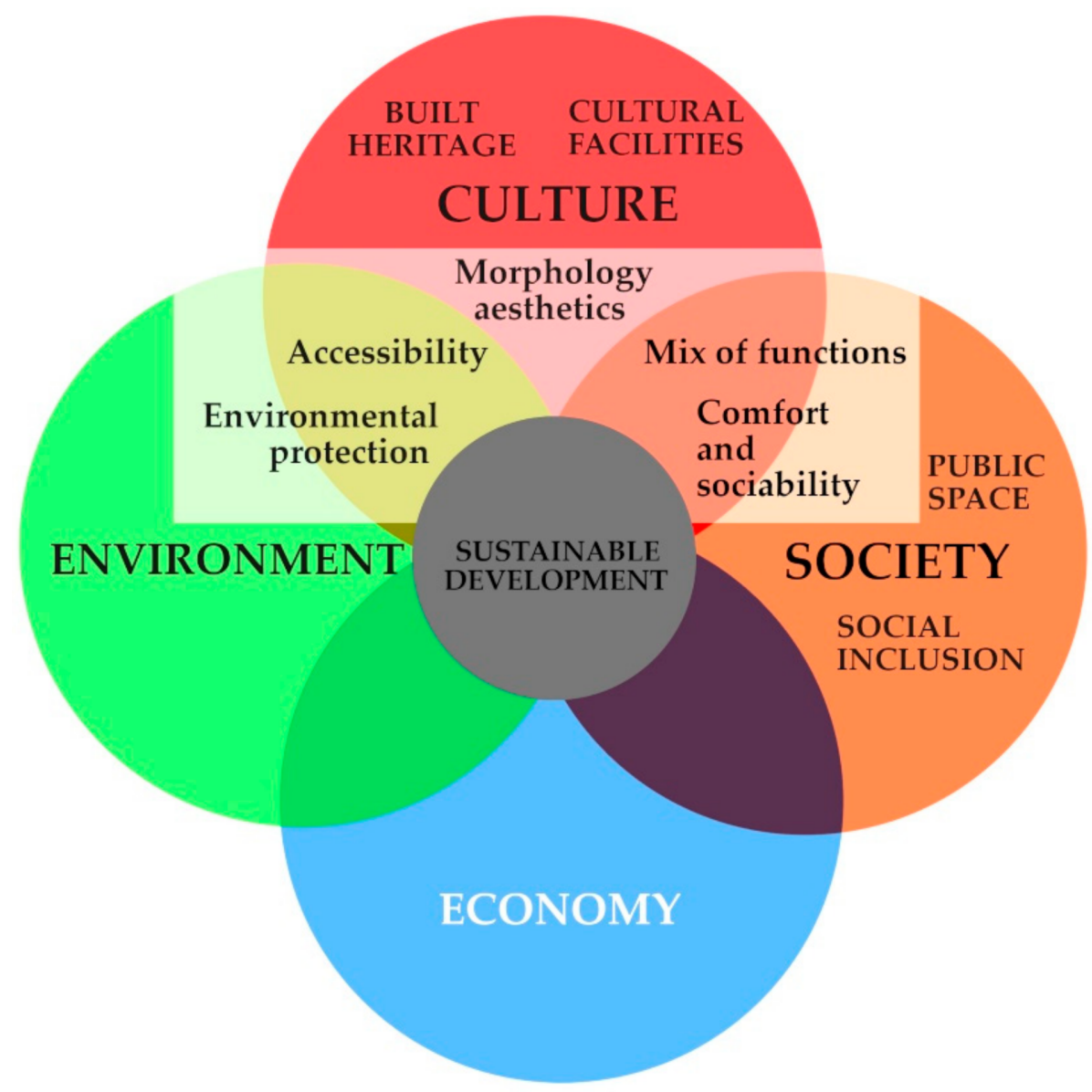

Figure 1. Scope of the research.

\subsection{Sustainability and Culture}

Despite a considerable amount of research on sustainability [20,21] and an emerging number of studies that link this issue to the functioning of cultural buildings in the urban fabric [22], a research gap in this topic is still present. This has been confirmed by Petti, Trillo and Tsube Macone who focus on gauging the implementation of the SDGs with reference to cultural heritage and recommend 'future research into the pluralistic values and impact of cultural heritage in achieving sustainable development' [23]. The lack of the 
studies on the functioning of buildings excluding their main cultural functions, but related to the surrounding public spaces, should be remedied by helping these facilities and areas to function more effectively for city residents. This is particularly relevant given the fact that the majority of the European metropolitan and smaller town centres are historic areas that should be subject to the process of achieving the SDGs alongside new developments. Dessein et al. [24], in the article entitled 'Culture in, for and as Sustainable Development', established three models of the relationship between culture and sustainability: (1) culture as an achievement in development, (2) culture as a resource and condition for development and (3) culture as a semiosis and development as a cultural process [25]. Of these three models, even the first one requires extensive measures in terms of urban sustainability. The development of cultural buildings in cities as public spaces can serve the purposes of walkable communities [14], or implement the six core design theories for health and well-being characterised by Cushing and Miller [26]. This model of linking culture and sustainability addresses the notion of culture and heritage most concisely (as the fourth pillar of sustainable development alongside the ecological, social and economic pillars). Nonetheless, it requires further research and implementation of measures for cultural institutions other than those directly related to the mission and programme activities of museums, as examined by Stylianou-Lambert et al. [27] and characterised by McGhie [28]. According to Dessein et al., the model risks being a limited approach, however, focused on protecting assets deemed cultural that are valued ('giving culture a voice of its own and an equal value'); it is sometimes too easily limited to a narrow definition of culture as the arts and creative-cultural sector [24].

Despite the concept of cultural sustainability and the 2015 ICOMOS (International Council on Monuments and Sites) declaration being introduced [29], there is published research that presents this issue with reference to the socio-economic post-communist reality conditioning the urban space in Central European countries. Moreover, apart from a few exceptions [22], the operation of the cultural buildings in Polish cities is commanded by museums. The research conducted by museums is mainly limited to the reception of their offers by visitors [30], whereas no evaluation takes into account their auxiliary functions, the layout of spaces enabling and customising their use and the public access to external space. This model of use or the problem of excluding these areas from the functioning urban fabric emerged during the COVID-19 pandemic, when the lockdown of cultural institutions in Poland (and elsewhere) resulted in the creation of deserted (ghost) spaces within the urban fabric. As the events of 2020 showed, the future is unknown [31]. According to a plausible hypothesis, Krakow, which has been packed with tourists until now [17], will have less tourist traffic and cultural institutions will be visited by fewer individual tourists and organised groups (also due to periods of distance learning). At the same time, due to periods of partial or total lockdown, the urban space is used for recreation and sport to a greater extent than before [32], and new methods of using it are emerging, such as the search for non-standard and small-group outdoor activities. Outdoor recreation and observing others are becoming even more desirable in public spaces than previously reported by Gehl [33], Carmona [34], London [14] and Cushing and Miller [26].

\subsection{Research Aims}

The following research aims to evaluate the spatial-functional potential of cultural buildings in the historic urban fabric for achieving sustainable development.

The following specific aims correspond to the general objective:

1. Examining which SDGs and to what extent are met by the buildings analysed in Krakow.

2. Examining how these buildings are perceived by the city residents. Do the citizens notice and respond well to the principles of urban ecology used in buildings?

3. Examining how these buildings operate during the pandemic. Are they likely to be flexible, inclusive spaces for other unforeseen events? 
4. Finding a correlation between the formal (aesthetic) and functional shaping of space and the perception and use of space.

The research objective is the evaluation of contemporary cultural buildings in the historic central urban structure of Krakow (the area entered into the UNESCO World Heritage List and its buffer zone) in terms of urban ecology and inclusive, liveable and walkable public space. The findings are collated with municipal strategies.

The applicational relevance of the study for cultural and urban management professionals, as well as designers and environmental psychologists, consists of the search for a new design model in the historic urban tissue of Krakow. The identification of the shortcomings and correction of individual problems within cultural sustainability would enable the fulfilment of all six aspirations of the city set out in the strategy [19], as shown in Figure 2.

HUMAN AND SOCIAL CAPITAL

\section{SMART PEOPLE}

the initiators of changes in the city should be the residents who, thanks to their high level of qualifications and competences, creativity and cooperation skills, with the support of information and communication technologies are able to strive to continuously improve the quality of

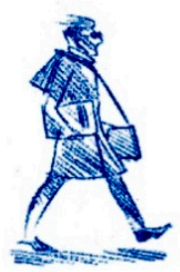
life in the city.
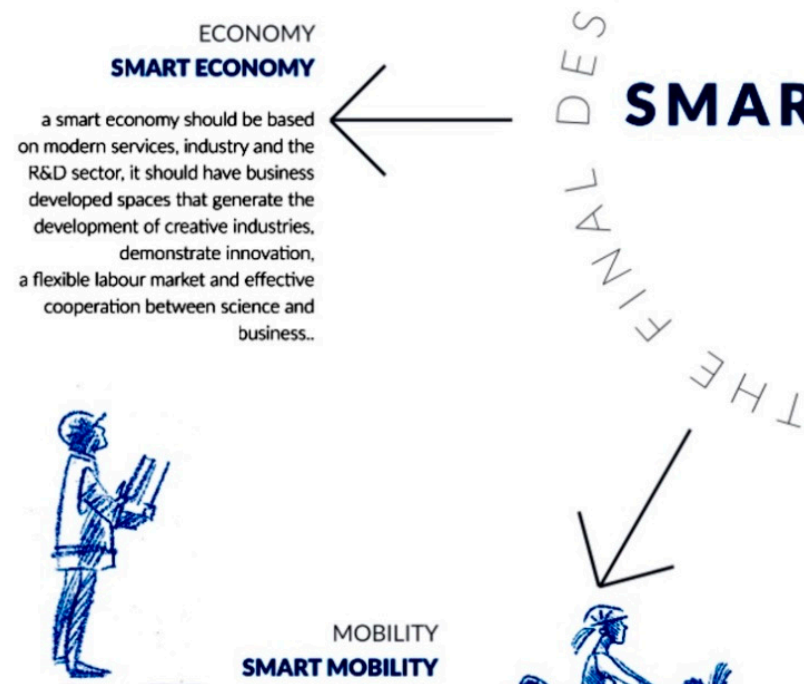

MOBILITY
SMART MOBILITY

the city should have an integrated and secure transport system that uses solutions from the information and communication technology sectors.

Thanks to the modern infrastructure, the city should create an effective network of high-speed connections, connecting all its resources

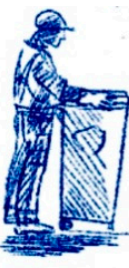

\section{NATURAL ENVIRONMENT} SMART ENVIRONMENT

a smart city optimizes its energy consumption, initiates actions to protect and adapt to climate change, introduces measures aimed at reducing emissions to the environment, and the management of the city's resources is based on the principle of sustainable development, using the infrastructure based on modem technologies.

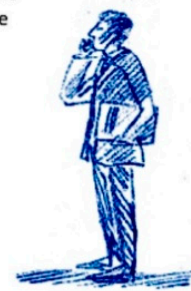

GOVERNANCE SMART GOVERNANCE

smart governance is understood as public management in which competences, social participation in decision making, transparency of actions and the high quality and accessibility of public sevices pand accessibility of public an important role. This requires the creation of an integrated city management system, taking into account the participation of all city users in achieving smart city goals and effective cooperation between the public and private sectors.

Figure 2. Smart city aspirations from Krakow's development strategy [19] (public domain). Publication developed on the basis of the contents of the Annex to Resolution No. XCIV/2449/18 of the Krakow City Council, multi-author text, editorial, graphic design E. Przybylska, graphic design M. Flis, translation IDEAGroup. 


\section{Materials and Methods}

\subsection{Selected Cases}

The case study concerns the centre of Krakow, Poland's second-largest city with a historic fabric inscribed on the UNESCO list, located in Central Europe. This geopolitical situation is associated with limited economic resources in public institutions and problems resulting from the post-war development characteristics. In the second half of the 20th century and at the beginning of the 21st century, the historic fabric of Central European cities was first surrounded by modernist housing estates, then by low-rise detached and semi-detached sprawling development patterns and more recently by pathological dense multifamily housing developments devoid of greenery and public services. Central European cities are also overcoming deficiencies in transport infrastructure and public institutions as they are characterised by the underdevelopment of metropolitan functions [35]. Such conditions necessitate the search for sustainability in small-scale solutions with limited resources rather than high-budget engineering solutions. The study defines cultural buildings constructed after 1989 (Poland's liberation from Soviet domination and the transition from a centrally planned to a capitalist economy) as contemporary ones. Redeveloped or renovated sites are not examined. The spatial delimitation includes Krakow's UNESCO protection zone together with its buffer zone (Figure 3).

In terms of sustainability, Krakow was examined by Zachariasz, presenting its historic and contemporary green areas [36]; Telega, Telega and Bieda, measuring walkability with GIS [37]; Jarosińska and Gołda, opting for protecting the existing green areas [38]; Gyurkovich and Gyurkovich, analysing New Housing Complexes in Post-Industrial Areas [39]; and Dudzic-Gyurkovich, assessing urban development and compositional pressure in Mlynowka Park [40], among others. Porebska et al. [41] evaluated flood protection against the UNESCO world heritage site protection, while Kwartnik-Pruc and Trembecka [42] focused on the implementation of the Public Green Space Policy. In terms of culture, the city is the capital of the province, with the largest number of cultural centres in Poland [43]. Some of the city's contemporary cultural buildings have been researched by Jagodzińska in numerous publications ([44] among others) and Gyurkovich ([45] among others). Its cultural infrastructure is examined in terms of its offer and the residents and tourists who use it, as well as its reception [46]. The author has identified a research gap in the form of a functional-spatial analysis of contemporary cultural facilities in Krakow and their reception by city residents. Polish cultural institutions have been studied in terms of organised events and participants [43], but no clear link between new cultural buildings and sustainability has been shown.

At the same time, the observation of selected examples of cultural buildings in the historic fabric of Krakow and the analysis of relevant documents have revealed that the idea behind building these cultural facilities (coming from the municipal authorities most often) was to increase the offer of the city and districts, encouraging people to settle near the city centre and workplaces, which also contributes to the idea of the sustainable compact city $[45,47]$. The model of a cultural building in the space of Krakow after 1989 can be characterised as buildings on small plots in the city centre. Ten facilities were built in the UNESCO zone and buffer zone, and three outside them. Being a cultural heritage area, the research site is subject to a series of conservation acts affecting the form of buildings. The small size of the plots results in limited space for auxiliary functions, car parks and surrounding greenery. 


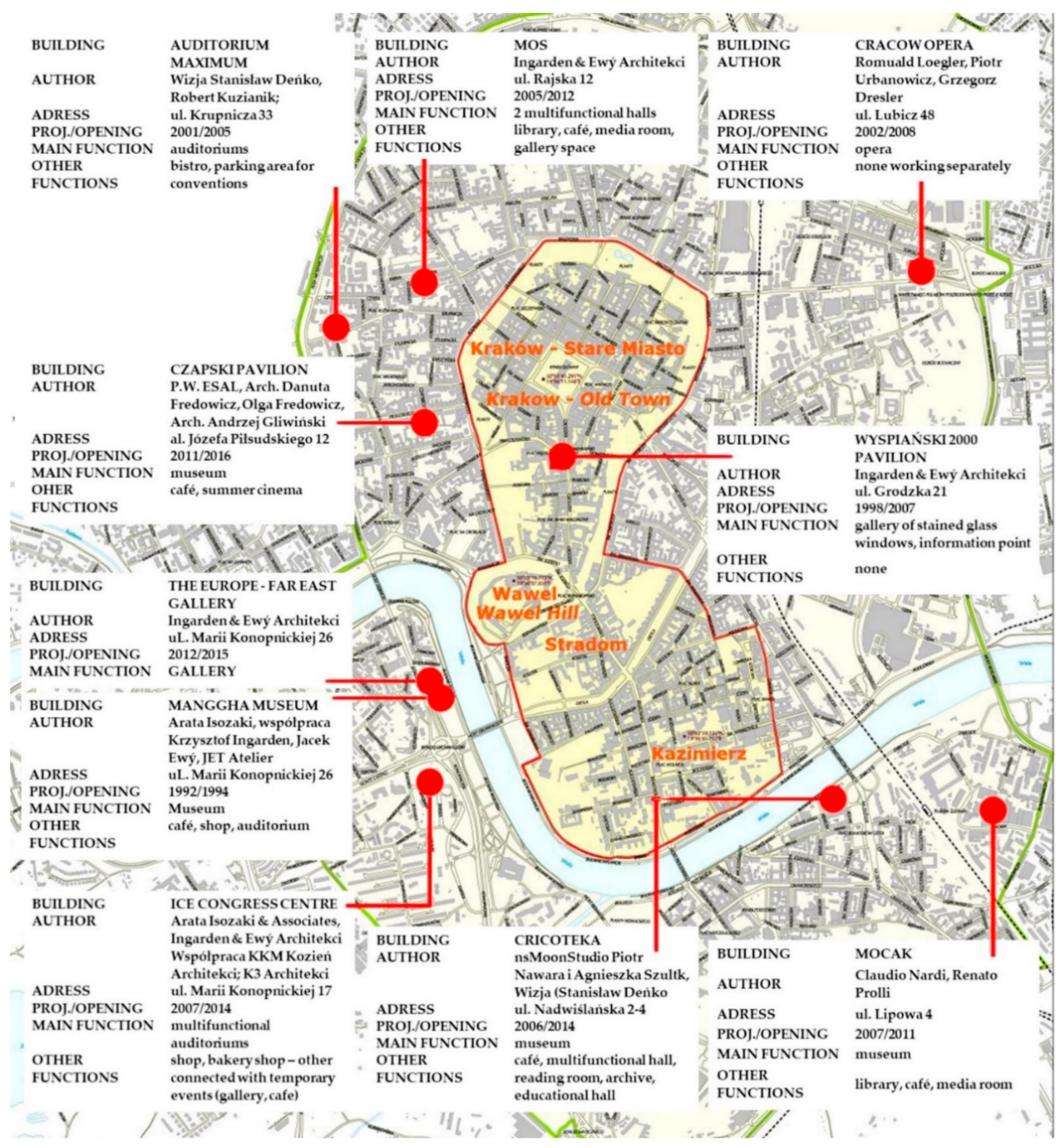

Figure 3. Map of cases shown in the map of inscribed World Heritage property. Red dots-location of cases. Red lineborders of the area entered into the UNESCO World Heritage List. Green line-buffer zone borders. Elaborated by the author, adapted from ref. [48] (public domain).

Figures 4 and 5, Supplementary Material S1 presents the analysed buildings. 


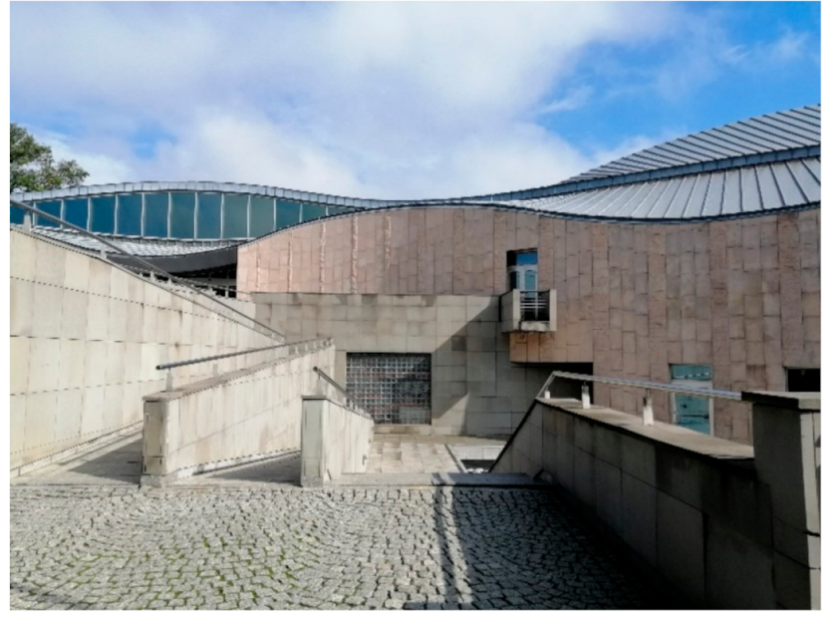

(a)

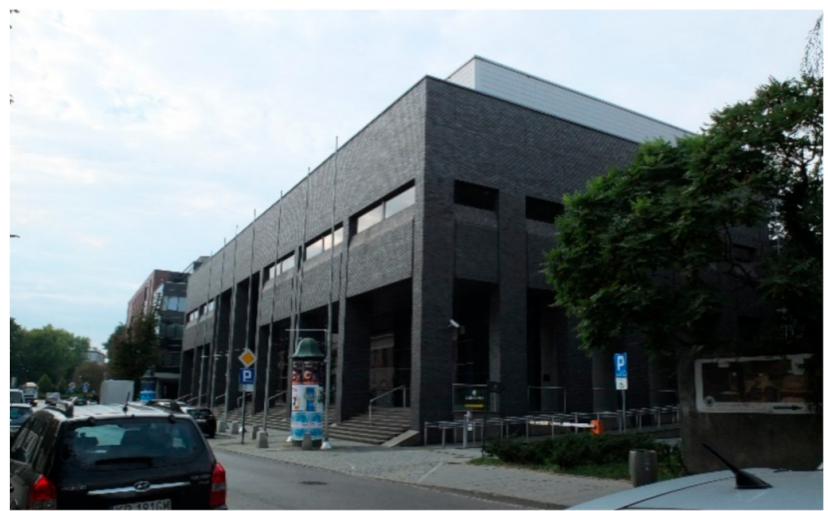

(c)

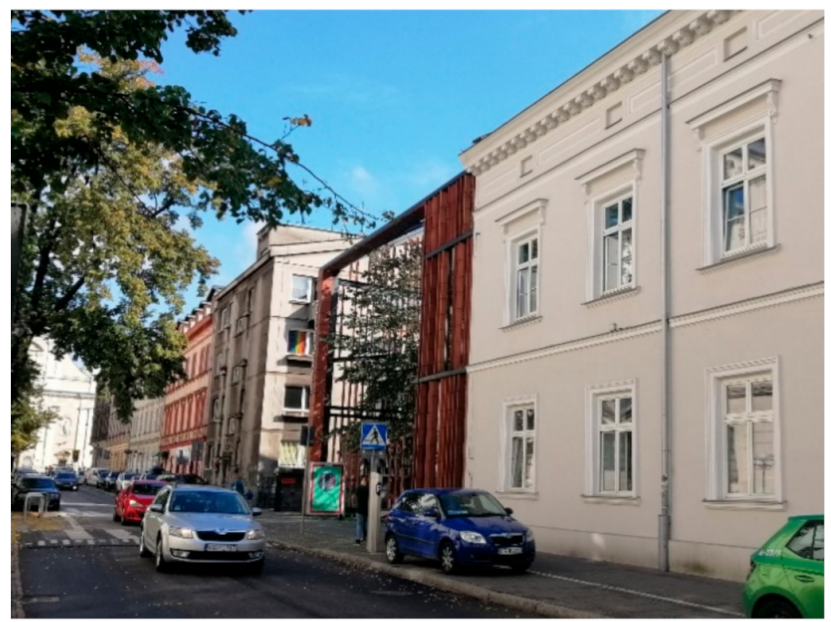

(e)

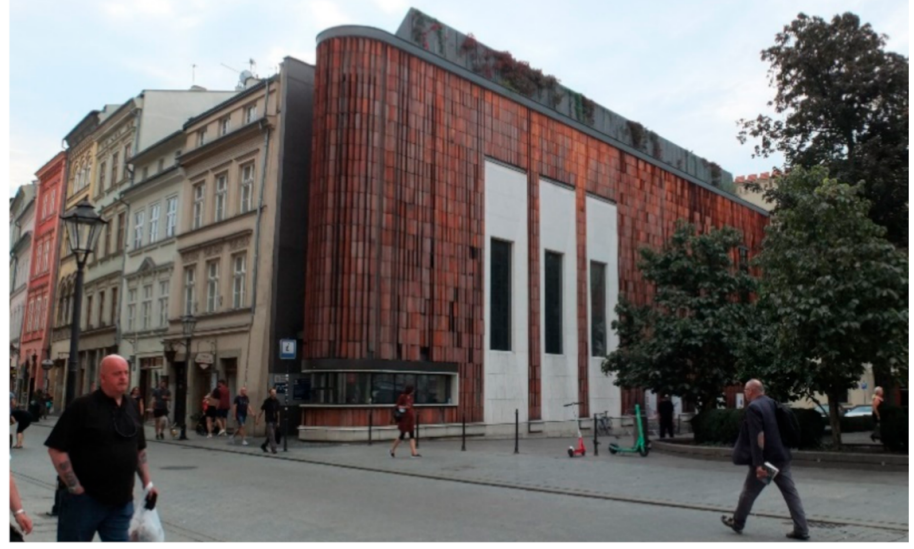

(b)

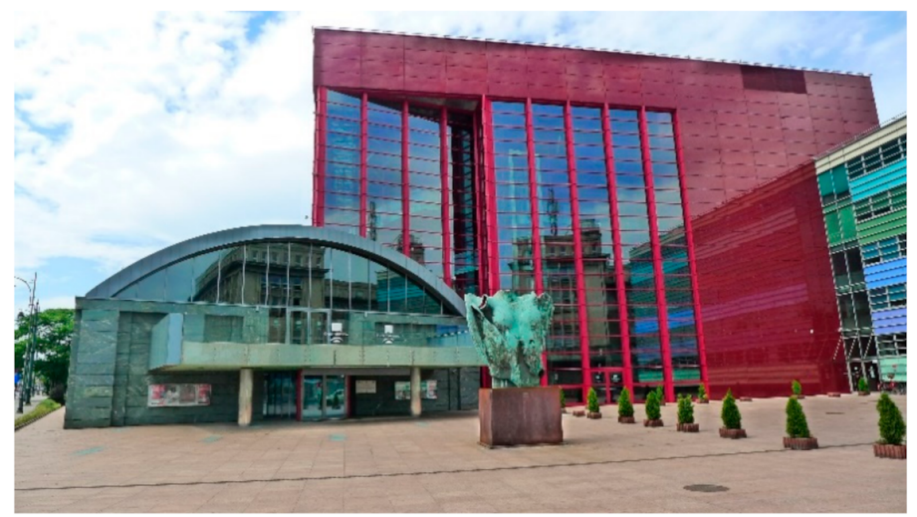

(d)

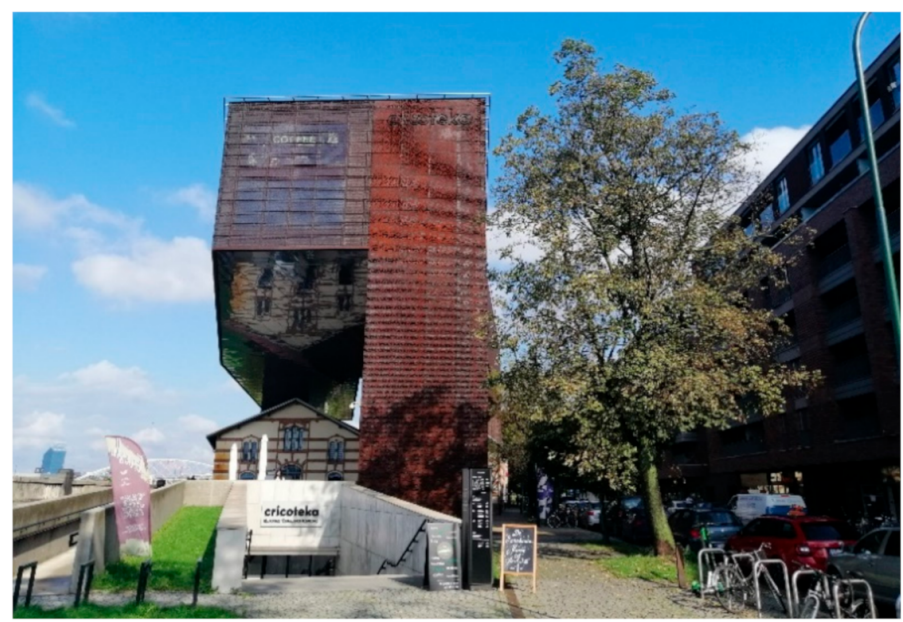

(f)

Figure 4. (a) Manggha museum; (b) Wyspianski Pavilion; (c) Auditorium Maximum; (d) The Opera House; (e) MOS; (f) Cricoteka. Photos by the author. 


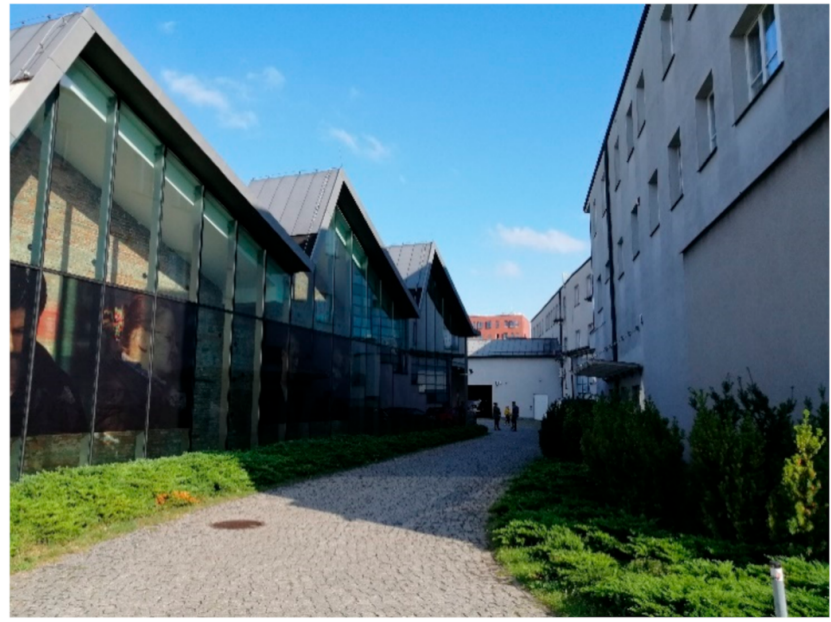

(a)

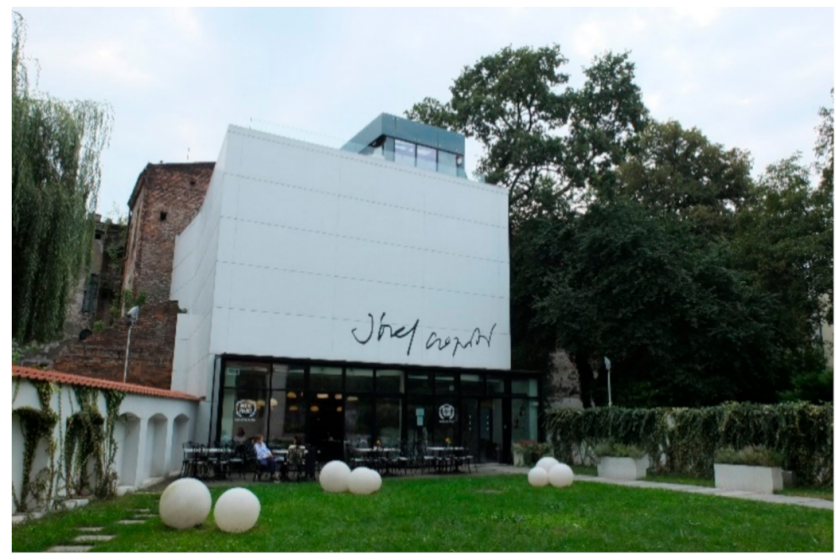

(c)

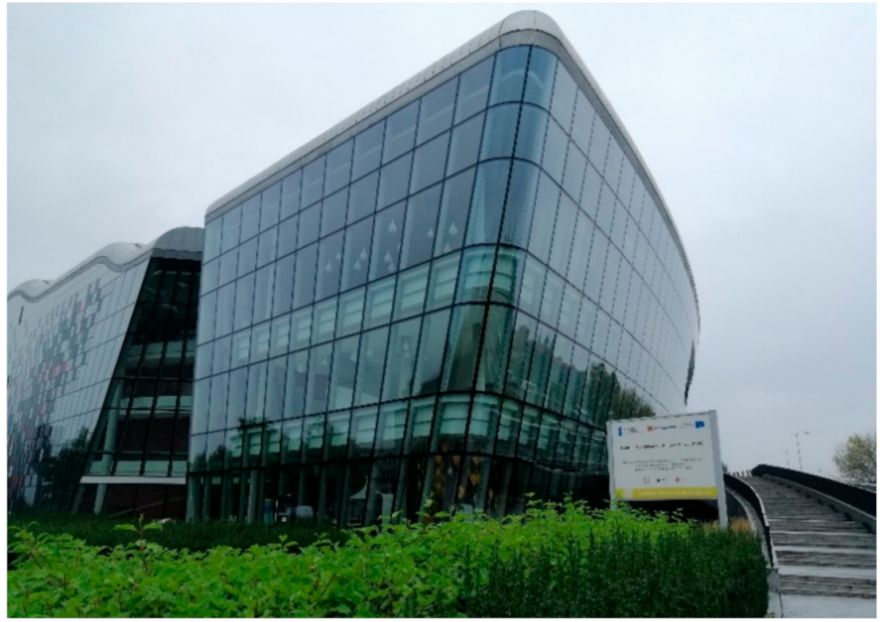

(b)

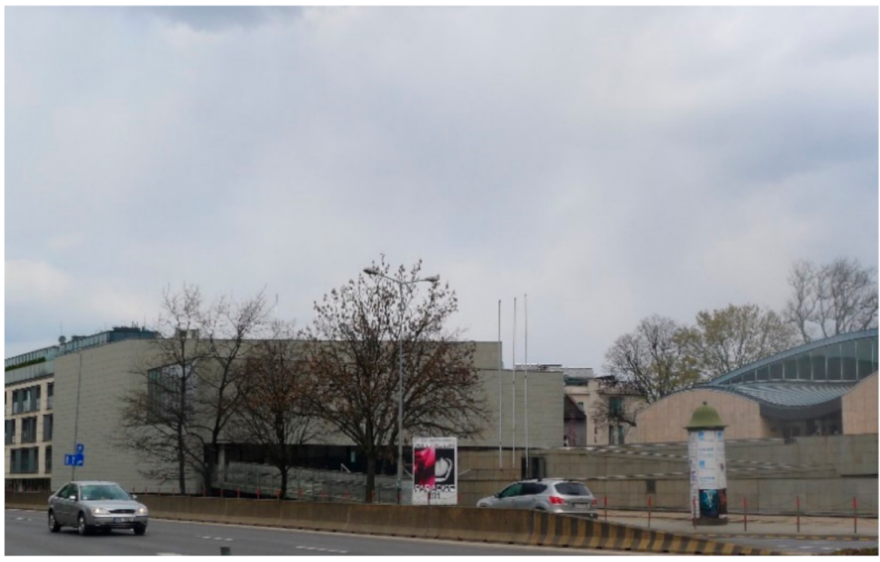

(d)

Figure 5. (a) MOCAK; (b) ICE; (c) Czapski Pavilion; (d) Manggha complex: The Europe-Far East Gallery. Photos by the author.

\subsection{Mixed Methods}

The research employs Creswell's concurrent triangulation mixed methods approach which produces reliable results in a relatively short time [49]. The author collected qualitative and quantitative data separately by means of observation, survey and behavioural mapping and then compared them. The methods were chosen because the preliminary study, which was a qualitative evaluation of a selected case (the Krakow Opera), indicated the need to support the observational results with quantitative data. This approach is justified by Silverman, among others [50]. The author combined three methods, giving priority to method A due to limitations of methods B and C. The research methodology is presented in Figure 6. The research phases, methods and techniques are listed in Table 1. 


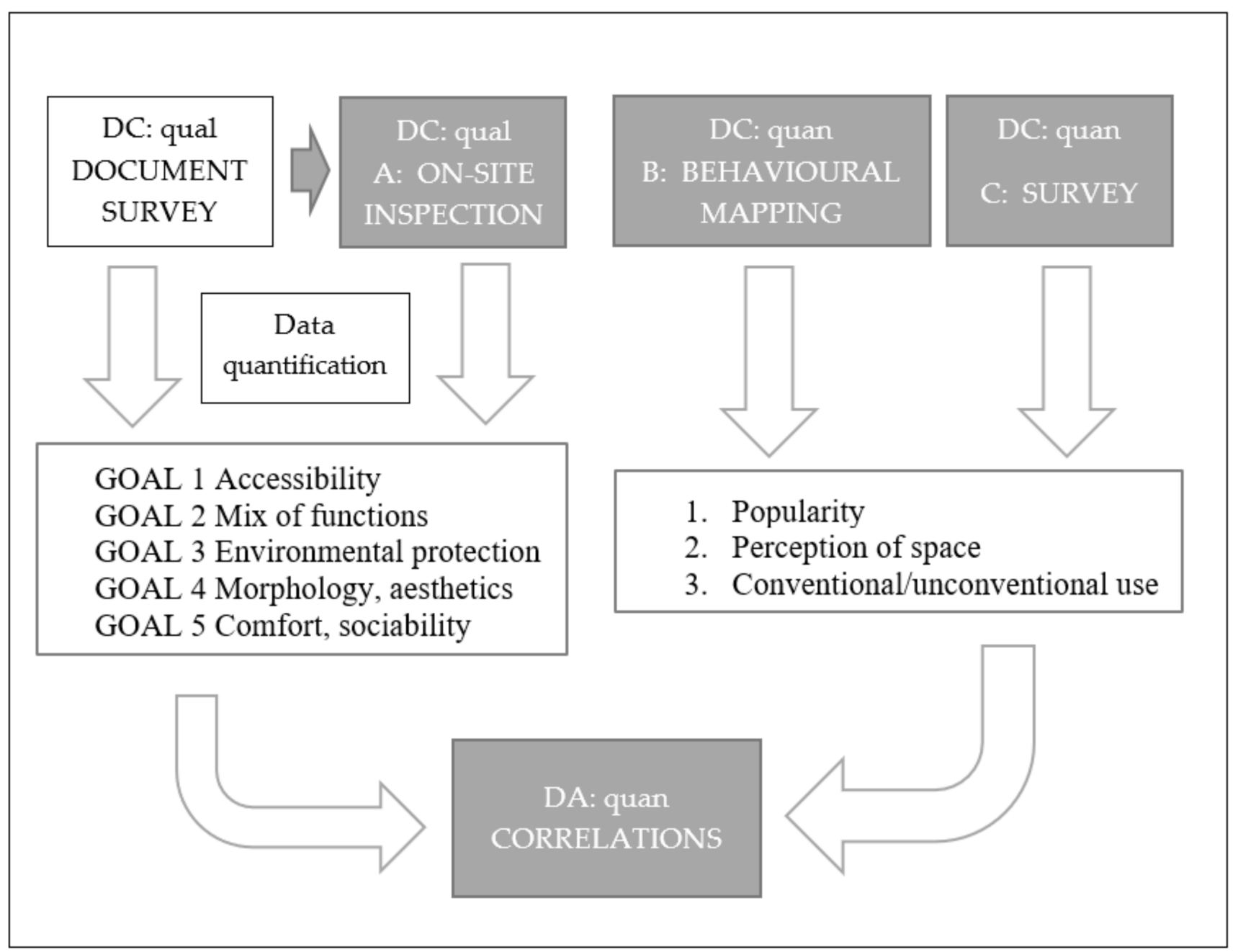

Figure 6. Research diagram. DC, data collection; DA, data analysis; qual, qualitative data; quan, quantitative data.

Table 1. Research methods and techniques.

\begin{tabular}{|c|c|c|c|}
\hline & Method & Technique & Specific Purpose \\
\hline \multirow[t]{3}{*}{ A. } & \multirow{3}{*}{$\begin{array}{l}\text { field research, } \\
\text { literature and } \\
\text { document review }\end{array}$} & $\begin{array}{l}\text { review of authors' published descriptions, drawings of the buildings } \\
\text { and magazine articles }\end{array}$ & \multirow{3}{*}{$\begin{array}{l}\text { indication of the degree of } \\
\text { fulfilling } \\
\text { urban ecology determinants }\end{array}$} \\
\hline & & review and critical studies of city strategies, statistical data & \\
\hline & & on-site inspection (query, critical studies, notes, photos, walkthrough) & \\
\hline B. & $\begin{array}{l}\text { behavioural } \\
\text { mapping }\end{array}$ & behavioural mapping & $\begin{array}{l}\text { analysis of the social } \\
\text { perception of spaces and how } \\
\text { the spaces function during the } \\
\text { pandemics }\end{array}$ \\
\hline C. & survey & a survey among inhabitants of Krakow & $\begin{array}{l}\text { analysis of the social } \\
\text { perception of spaces }\end{array}$ \\
\hline
\end{tabular}

\subsubsection{Method A}

The on-site observation and document review served as a qualitative and quantitative assessment of five groups of spatial factors that contribute to the realisation of the following five goals:

GOAL 1 Accessibility - the visual accessibility and infrastructure provision, as well as the quality of walking, cycling and public transport, have been assessed with respect to road transport and the needs of the disabled. 
GOAL 2 Mix of functions-the number and variety of functions in and adjacent to the cases assessed, their arrangement, accessibility and presence in the external space have been assessed.

GOAL 3 Environmental protection-the quantity and quality of green infrastructure, pro-environmental solutions applied in buildings, including ways to reduce the urban heat island effect, have been assessed.

GOAL 4 Morphology, aesthetics - cultural heritage, urban morphology as well as image, forms and aesthetics of space were assessed.

GOAL 5 Comfort and sociability - the quality of space and social potential have been assessed.

Table 2 presents the source of the analysis criteria adopted based on the literature review. The criteria have been adopted drawing on expert knowledge in the field of architecture and urban planning. A five-point assessment scale is used for each factor.

Table 2. References of research tools in the method A.

\begin{tabular}{|c|c|c|}
\hline Reference & Tool/Selection of Features Based on & Indicators \\
\hline Gehl [51] & 'Life between buildings' & goals 1,5 \\
\hline Kesik [52] & 'Analysis of Pavements for Disabled Pedestrians in Metropolitan Cities' & goal 1 \\
\hline Place Alliance [34] & The Ladder of Place Quality & goals 1,4 \\
\hline NACTO [53] & 'Urban Bikeway Design Guide' & goal 1 \\
\hline London [14] & 'Healthy placemaking' principles assessment methodology & $\begin{array}{l}\text { goal } 1 \\
\text { goal } 2\end{array}$ \\
\hline Gehl [33] & $\begin{array}{c}\text { Quality criteria for the pedestrian environment, analysing ground floor } \\
\text { of neighbouring buildings }\end{array}$ & goals $1,2,4$ \\
\hline Cushing, Miller [26] & 'Creating great places', Salutogenic design & goal 2 \\
\hline Lehmann [54] & $\begin{array}{c}\text { The } 15 \text { Principles of Green Urbanism: Energy and Materials, Water and } \\
\text { Biodiversity }\end{array}$ & goal 3 \\
\hline Elliott, Eon, Breadsell [55] & GIDS to urban cooling & goal 3 \\
\hline $\begin{array}{l}\text { US Environmental Protection } \\
\qquad \text { Ag. [56] }\end{array}$ & 'EPA Heat Islands Cooling Strategies' & goal 3 \\
\hline Center for Active Design [57] & 'Assembly: Civic Design Guidelines', Incorporating nature criteria & goal 3 \\
\hline Project for Public Spaces [58] & ‘What makes a great place?’ & goals 4,5 \\
\hline Lewicka [59] & $\begin{array}{l}\text { characteristics of a phenomenological conservative concept of a place } \\
\text { (as opposed to a non-place) }\end{array}$ & goal 4 \\
\hline Lofland [60] & elements contributing to the satisfaction of staying in a public space & goal 4 \\
\hline Gehl Institute [61] & 'The Inclusive Healthy Places Framework' & goal 5 \\
\hline
\end{tabular}

\subsubsection{Method B}

The fourth stage of the research involved behavioural mapping of the space around buildings using the snapshot method. The author observed the behaviour of pedestrians around the buildings, counted and classified them. The method aimed to see which venue generates the most traffic and what activities take place there, regardless of its cultural offer. This will allow one to discover the vitality of a place independent of the attractiveness of the programme offered by the cultural institution, and therefore lasting even during the pandemic.

The author visited all the places three times:

1. 23 September / 2 October 2020-13:00-14:30;

2. 3 October 2020-16:40-17:50;

3. 6 October 2020-11:15-13:00. 
Each visit took place in similar weather conditions for all the cases, i.e., approximately $20{ }^{\circ} \mathrm{C}$. Such weather allowed the reflection of the environmental potential of the site as the aim was to compare behaviour in the spaces of the sites between them. During each 5-min visit at one location, the author counted the number of users and divided the people observed into three groups: users, passers-by, employees.

The behavioural mapping tool and the counting were based on the evaluation by the Project for Public Spaces [58] and Mantey's research that concerned the public spaces of Warsaw's suburbs [62]. Due to the need to move quickly between the buildings to obtain comparative results, the results were not plotted on a map but entered into a table.

The correlation between the results of the mapping and method A (on-site inspection with document survey) was examined. The author assumes that there should be a correlation between the outcomes of this method and the survey.

\subsubsection{Method C}

The author collected 173 questionnaire survey responses from Krakow's residents who were randomly assigned to the sample. The survey aimed to generalise the data from the sample and obtain conclusions about the perception of the buildings under study and the space around them. The survey method ensured quick collection of a large amount of data, quick orientation in the data set and access to the most diverse group of people providing information. The author aimed to collect the largest possible sample to obtain the most authoritative results.

The first phase of the research was conducted in September 2020, employing selfcompletion paper-based questionnaires, distributed by the author and her friends (20 questionnaires). To ensure the most reliable results, the author wanted to reach people who do not necessarily or rarely use the Internet. However, due to the need to increase the sample size in a shorter period and the threat of discretionary sampling and the presence of an interviewer skewing the results, the author decided to change the survey method to online self-completion questionnaires, ensuring a random selection of individuals. The author treated this phase as a pilot test, later included in the final results.

Subsequent surveys were conducted and collected in two rounds via Survio (free version) in October 2020 and March and April 2021 propagating information about them via Facebook in the following groups: Spotted Krakow, Krakowskie Mamy, Stowarzyszenie Architektów Oddział Kraków, Spotted Vilo. The survey was designed as a cross-sectional study. Due to the need to collect more data from people aged 60 and over, the author introduced a questionnaire distributed to the U3A (University of the Third Age) students in a further stage.

The survey included respondents' particulars, presented in the table below (Table 3). This was not used to compare data, but to check on an ongoing basis whether the overrepresentation of any group (e.g., age or artistic occupations) would not potentially skew the outcomes.

The core part of the questionnaire inquired, with regard to each facility under study, whether the respondent:

1. Knows the building;

2. Likes or dislikes each building;

3. Wants or does not want to enter the building when they are nearby;

4. Likes or dislikes its surroundings;

5. Wants or does not want to spend their free time around the building;

6. Feels the space around the building is suitably spacious (or too small/too big);

7. Feels that there is or there is not enough greenery there;

8. Will or will not come back to that place.

The full questionnaire is included in Supplementary Material S2. 
Table 3. Respondents' particulars contained in the survey.

\begin{tabular}{cr}
\hline Question & Possible Answers \\
\hline How old are you? & 18-26/27-35/36-59/60 and over \\
\hline What is your education? & Primary/lower secondary/vocational/upper secondary/higher \\
\hline $\begin{array}{c}\text { Do you have a profession related to art (painter, sculptor, } \\
\text { architect, conservator, actor, musician, etc.)? }\end{array}$ & Less than one year/1-2 years/3-5 years /6-10 years/More than \\
How many years have you lived in Krakow? & $\begin{array}{c}\text { Several times a month/About once a month/About once a } \\
\text { quarter } / 1-2 \text { times a year/Less often or not at all }\end{array}$ \\
\hline $\begin{array}{c}\text { How often do you use the city's cultural offer (exhibitions, } \\
\text { cinema, theatre, etc.)? }\end{array}$ &
\end{tabular}

The responses to questions $2-8$ about each building could be given on a five-point semantic scale $(-2,-1,0,1,2)$. In the online survey, the slider was initially set to 0 . The answers to these questions were not mandatory as the respondents might not have been familiar with all the buildings. As the slider remained in the 0 position when no response was given, the results did not reflect the specific number of responses from each group. However, the analysis of the number of options selected $-2,-1,1,2$ allowed for a caseby-case comparison. The author compared total scores being the products of ranks and frequencies of similar responses for each case. A stratified sample with equal allocation was applied. The data were presented on a semantic differential scale.

The data were used to compare buildings between individual cases in terms of perception of space in three groups of issues: knowledge of the building (I: question 1), positive or negative attitude towards space (II: questions 3, 4, 5, 6, 9) and perception of specific elements of space (III: questions $2,7,8$ ). The questions in group II examined the distinctive and memorable appearance of the space, appreciation of the building and its surroundings, willingness to go inside or spend time next to it, as well as the willingness to return to this place. In group III, respondents answered additional questions concerning the accessibility by public transport, the amount of greenery and the feeling that the space around the building is the right size.

The analysis of correlations between individual questions verified the accuracy of the responses (e.g., between relatively similar questions 2, 3, 4, 5) or yielded the results on the complete perception of the space around the building, the form of the buildings and the perception of the presence of greenery or openness of the space. In turn, the analysis of the correlation between the answers to the questions and the results of the mapping and analysis of the space provided a full spectrum of the findings.

\subsubsection{Correlations}

Correlations between individual survey responses and the results of on-site analysis and behavioural mapping were examined using the Pearson correlation coefficient. The following correlation intervals were adopted: $0-0.3$-weak correlation, $0.3-0.5$ - moderate correlation, $0.5-0.7$ - strong correlation, $0.7-1$ - very strong correlation.

\section{Results}

\subsection{Method A}

In general, in this phase of the study, MOS (Polish for The Małopolska Garden of Arts) and Cricoteka received the best scores, while the Krakow Opera and the Auditorium Maximum received the worst and lowest scores. The graph in Figure 7 presents a comparison of the results of the on-site analysis, spread over different groups of attributes (goals 1-5). 


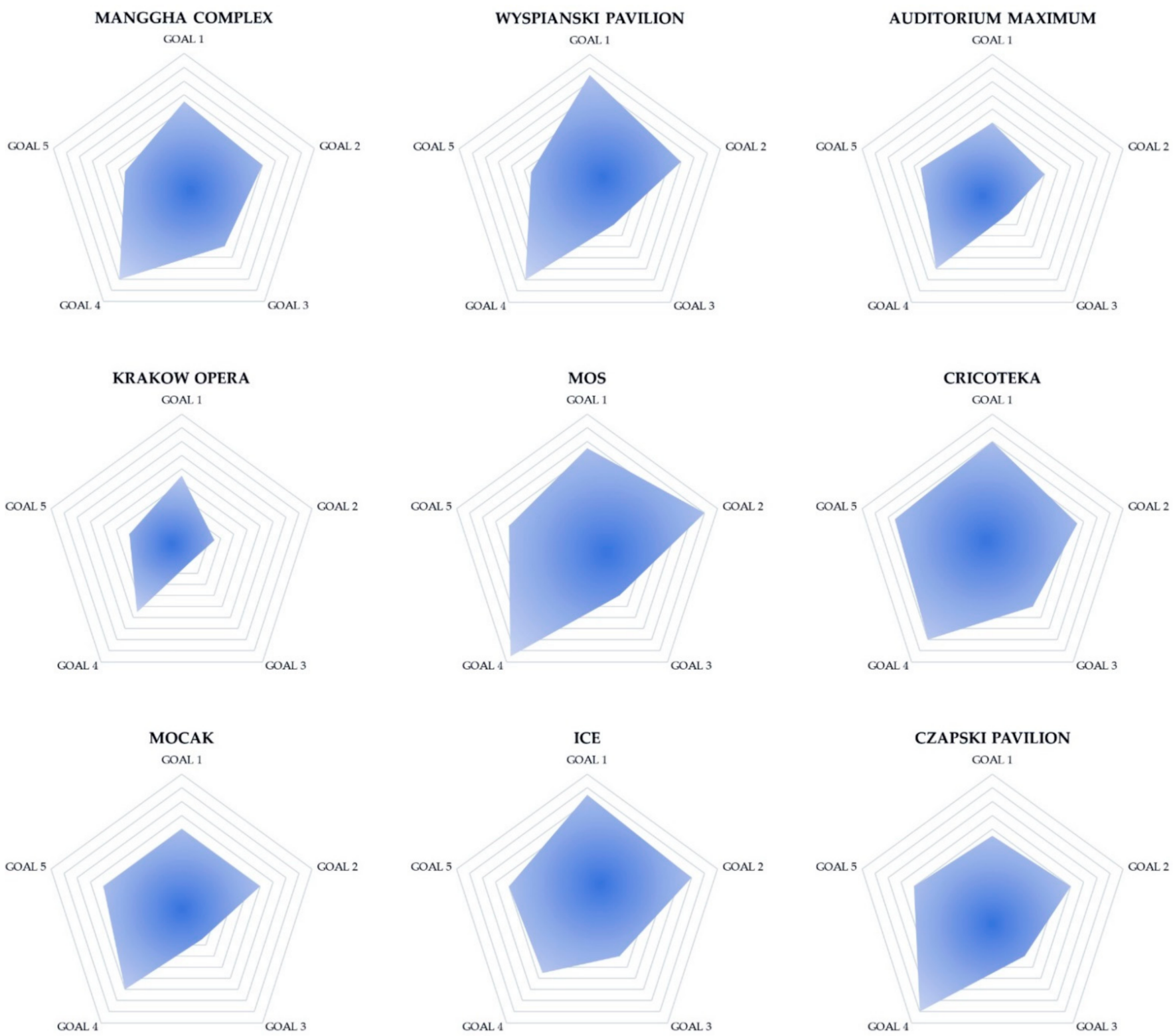

Figure 7. Summary of the results of method A.

The cultural facilities inscribed on the UNESCO World Heritage List in Krakow and in its buffer zone were built on degraded, disused plots of land (e.g., MOCAK, MOS, Cricoteka, Krakow Opera) but are now revitalising those neglected spaces by introducing new functions. MOCAK (the Museum of Contemporary Art in Krakow) has become one of the focal points of the now highly popular district of Krakow. In some cases, the effect of urban acupuncture is visible, e.g., the space around the ICE Congress Centre is gradually changing from neglected wasteland to new and renewed plots. In turn, the former workingclass neighbourhoods around MOCAK and Cricoteka with their numerous cheap vacant lots left after the closure of factories have become a Mecca for new enterprises, such as art galleries, studios and workshops. The existing town centre has been redeveloped and revitalised. The buildings-as large as the local plans allow-have densified the surrounding areas. Through this densification process, Krakow seeks to be a compact city with sustainable and self-sufficient neighbourhoods. Most of those facilities form the nucleus of cultural and entertainment spaces. 


\subsubsection{Goal 1}

Table S1 in Supplementary Material S1 presents the detailed results of the analysis in terms of sustainable transport and visual accessibility. The Wyspianski Pavilion, Cricoteka and ICE are rated best as far as the quality of walkability, cycling infrastructure and access to public transport are concerned. Auditorium Maximum scored worst-the building is located near the busy Trzech Wieszczow Avenues, poorly connected for cyclists and hardly visible from afar.

All of the analysed buildings are easily accessible on foot, although access to the Krakow Opera and Manggha is hampered by proximity to busy streets. Krakow is striving to improve the quality of the pedestrian environment by banning individual cars from the city centre, limiting maximum speed and extending paid parking zones. It is a walkable space with no barriers for pedestrians in most cases, occasionally disturbed by the multitude of cars parked in front of the buildings (Auditorium Maximum, Cricoteka) or even on their premises (the Krakow Opera, MOCAK).

During the pandemic, municipal authorities introduced several traffic changes, e.g., converting car lanes into cycle lanes. It should be mentioned, however, that although Krakow claims to be a cycle-friendly city, only two of the analysed venues are accessible by cycle lanes (ICE, the Krakow Opera). The other three can be reached by both pedestrian and cycle lanes; the rest by counterflow lanes, pavement or riding in city traffic. All nine of the buildings have bicycle stands, but their number varies.

Access for wheelchair users is usually provided from ground level or via a ramp but access to the Jozef Czapski Pavilion is hindered by the uneven surface of the cobbled pavement.

The location in the very centre of the city provides good access to all the facilities via public transport. The distance from the public transport stops varies between 50-390 m. MOCAK, Cricoteka and the Krakow Opera are also located within 350-900 m from the railway stations-a means of agglomeration transport.

The visual accessibility is most effective when the facilities are located by the Vistula River (Manggha Centre, Cricoteka) and near the less densely built-up Grunwaldzkie and Mogilskie Roundabouts (Manggha Centre, ICE and the Krakow Opera). The Wyspianski Pavilion is also well visible from various points in the Old Town, whereas the Jozef Czapski Pavilion, Auditorium Maximum and MOCAK are hidden within the dense fabric.

\subsubsection{Goal 2}

The MOS and ICE were rated best in terms of mixed-use programmes, contributing to the liveability and health of the community, while the Krakow Opera and Auditorium Maximum were rated worst as far as this aspect is concerned. Table S2 in Supplementary Material S1 shows the results.

Better results are related to more features available at different times of the day, including those that are free of charge and available during the hours when the main cultural area is closed. The worst results correspond directly to the limited programme of functions that are unavailable independently, resulting in the abandonment of a given space during the lockdown of cultural and educational institutions.

The analysis also included functions in the immediate surroundings of the buildings and adjacent public spaces. The results show maximum diversity of functions in six out of nine cases in the adjacent development, but poor filling of public spaces with functions allowing for their optional use. These are usually cafés with tables outside. There is also an outdoor cinema in the Jozef Czapski Pavilion, a museum lapidarium beside it, and a nursery school garden right next to the MOS. Apart from these elements, there are no other functions for children or seniors or health-promoting functions. The presence of NGOs in the immediate vicinity is not visible, either.

Hence, general deficiencies are evident in this group of factors: the buildings are connected to culture but lack new models for cultural development and fostering creativity (such as affordable and flexible studio spaces in historic buildings and warehouses). 


\subsubsection{Goal 3}

Regarding climate change mitigation, green spaces are present in all cases except the Krakow Opera, including a large green area at the Manggha Centre with a bamboo garden and a tea pavilion. In contrast, there are no water facilities next to the buildings to provide comfortable cooling and physical recreation, nor are there renewable energy solutions, a zero-waste concept or attention to shorter supply chains. There are no green roofs or walls, other than a single wall with climbing plants at the Wyspianski Pavilion.

Among other solutions minimising the urban heat island employed in the analysed cases, one can mention the use of light colours (white at the Jozef Czapski Pavilion, ICE and Manggha Centre) and canopies (the pergola at the MOS and the Cricoteka building that creates a roofed space itself-although the idea was scenographic rather than ecological). Apparently, the UHI reduction was not considered by all architects in their designs. The dark building of Auditorium Maximum certainly does not counteract the urban heat island.

Located in a valley, Krakow has ventilation problems that are not alleviated by new development. On the contrary, it is getting worse as the municipal authorities are gradually allowing for ventilation corridors to be built over. The buildings in question may not be the most problematic, but they do not help in solving the smog problem either. Table S3 in Supplementary Material S1 shows detailed results.

Along with the expansion of green areas for natural retention, these measures are in line with the municipal strategy for counteracting the effects of the urban heat island, heavy rainfall and flooding, as well as the exceedance of air pollution standards. While the more publicly accessible, shaded seating areas along the transport and walking routes are one of them, only cafés provide them at MOCAK and the Manggha Centre-i.e., they are paid and therefore not entirely public. There are mixed ratings for weaving natural elements into parks and playgrounds, designing public spaces to reflect local geography and supporting direct interaction with nature through free and low-cost activities. The Manggha Centre and Cricoteka reflect the local geography with their location by the Vistula River. In turn, the MOS, ICE and the Jozef Czapski Pavilion offer free-of-charge activities in their green spaces: an open-air cinema at the Czapski Pavilion, a congress square at ICE and a variety of activities in the greenery under the roof at the MOS, which are very popular with Krakow residents.

\subsubsection{Goal 4}

As far as urban morphology and aesthetics are concerned, a compact, consistent pattern of development surrounds all the examples. It should be mentioned here that the city centre of Krakow has in general a pedestrian scale, a dense network of streets and natural surveillance. It is evident that the city is striving to find a balance between the preservation of historic heritage and new forms and functions of the buildings. In terms of the attributes listed, all examples were rated highly. Table S4 in Supplementary Material $\mathrm{S} 1$ shows the detailed results of the attributes in this group. The designers of the Krakow Opera and Cricoteka incorporated existing historic buildings into the new projects. The architects of the MOS and the Wyspianski Pavilion adhered to the historical alignment of the riding arena and the Lipka Tenement House, respectively. When designing MOCAK, Claudio Nardi Architects formally conformed to the characteristic development in the neighbourhood. The incorporation of the historic heritage into the new structures has added a heritage conservation value to the buildings. Furthermore, almost all the examples received total points as enclosed concentric authentic spaces characterised by genius loci and continuity of historic buildings in the place/non-place category following Lewicka's criteria [59]. Regarding the features of Lofland's sources of aesthetic pleasure [60], the places are characterised by perceptual innuendo, i.e., pleasure derived from glimpsing a small piece of the building (the canopy in front of the MOS from both directions of Rajska Street, the white façade of the Jozef Czapski Pavilion facing the courtyard of the Emeryk HuttenCzapski Museum, MOCAK seen from the entrances of the neighbouring streets) and unexpectedness or whimsy (the aforementioned examples as well as the curved roof of the 
Manggha Centre, the reflective underside of the overhanging in Cricoteka, the red glazed body of the building of the Krakow Opera). Historic Layering or Physical Juxtaposition between contemporary forms of the buildings and historic roofing is perceived in virtually all examples. Some of them offer the possibility of public solitude (Auditorium Maximum, the Jozef Czapski Pavilion, the Manggha Centre and the space at the rear of ICE), others stimulate diversity (the Wyspianski Pavilion, Cricoteka, the front of ICE).

The analysis of the ground floors of the buildings according to Gehl's criteria revealed that the most favourable situation-i.e., narrow fronts, numerous doors, diverse functions, façade relief and rich details-is present around the Wyspianski Pavilion, and the least favourable one occurs at the ICE Congress Centre.

\subsubsection{Goal 5}

Although the abovementioned examples have undeniable aesthetic qualities, acknowledged by numerous awards, the level of cleanliness of the space in some cases is low. The Wyspianski Pavilion is a neglected building (the renovation of its façade started in October 2020), polluted by pigeons, with homeless people present in the surroundings. The Manggha Centre is a dirty, crumbling building with bins and litter scattered at the back entrance. These facilities scored the worst, while the Jozef Czapski Pavilion was rated the best. Noise levels harmful to health, i.e., $\mathrm{LDWN}>65 \mathrm{~dB}$, occur in the vicinity of the Manggha Centre, Auditorium Maximum, the Krakow Opera and ICE.

The quantity and quality of seating (along with its adequate protection) was rated best at the Manggha and Cricoteka, and the least at the Krakow Opera. Regarding the other elements of street furniture (such as art in public space, furniture, facilities for children, seniors and the disabled), the results are fairly even since there are slightly different elements in each example. Overall, the MOS with its canopy, mural and bike stand as a spatial sculpture scored best, and Auditorium Maximum and ICE scored worst.

Detailed results for the group of five attributes can be found in Table S5 in Supplementary Material S1. The social capital assessment included in the table also encompasses the impact of a venue evident by the number of posts and followers on Instagram, the presence of collective actions and events in the surroundings and the number of people in the area that are not a crowd. Additional points were given if a restaurant, bistro or café was located in the building, which increases interest, also evident in behavioural mapping. Here, MOCAK and the ICE Congress Centre were rated highest, whereas the Manggha Centre was rated the lowest. For a description of the activities of the MOS, MOCAK and Cricoteka, see the final reports on the cultural sector survey $[46,47]$.

\subsection{Method B}

Behavioural mapping revealed that there is little traffic at open venues, which, according to tourism statistics [18], is most likely a lockdown effect on the use of public space (especially among tourists and organised groups). This effect is visible even in the case of open museums. The research showed a variation in the number of users of the space (see Table 4). The highest number of users could be seen at the Manggha Centre and Cricoteka, which may be related to their location by the Vistula boulevards. There were practically no people engaged in 'optional activities', according to Gehl's notion [51] near ICE, the Krakow Opera and Auditorium Maximum. These places lack greenery and auxiliary functions, but above all, created an urban interior that would allow for 'public solitude' or a place where one can sit down and enjoy a cup of coffee or a meal (the patisserie in the ICE Congress Centre is located at the rear of the building, facing a busy street).

The majority of passers-by, however, can be seen around the MOCAK building, located inside the city block. This place has 'taken root' in the district, becoming a pleasant thoroughfare. People walk their dogs there. Passers-by are hardly to be seen around the buildings located away from the main public spaces of the city (e.g., Auditorium Maximum, the Josef Czapski Pavilion), but there are plenty of them when the building is situated along a pedestrian route, as is the case with the Wyspianski Pavilion. However, the location of 
the Wyspianski Pavilion in the centre did not result in pedestrians entering the building or stopping by it. Therefore, they were not counted and included in the mapping table. They move 'independently' from the building and thus, there is no spontaneous activity around it. The situation looks better at the Jozef Czapski Pavilion, where there are no passers-by, but people can be seen sitting at the outdoor café tables.

Table 4. Mapping results.

\begin{tabular}{cccccccccc}
\hline & $\begin{array}{c}\text { Manggha } \\
\text { Complex }\end{array}$ & $\begin{array}{c}\text { Wyspian. } \\
\text { Pavilion }\end{array}$ & $\begin{array}{c}\text { Auditor. } \\
\text { Maxim. }\end{array}$ & Opera & MOS & Cricoteka & MOCAK & ICE & $\begin{array}{c}\text { Czapski } \\
\text { Pavilion }\end{array}$ \\
\hline employees & 6 & 0 & 2 & 4 & 1 & 11 & 7 & 11 \\
\hline passers-by & 4 & 5 & 0 & 3 & 15 & 2 & 18 & 4 \\
\hline $\begin{array}{c}\text { other users (café, } \\
\text { benches, etc.) }\end{array}$ & 38 & 0 & 0 & 0 & 11 & 34 & 13 & 0 \\
\hline all & 48 & 5 & 2 & 7 & 27 & 47 & 38 & 15 & 14 \\
\hline conclusions & UU & OU & OU, OP & OU & PP & UU & PP & OU & OP \\
\hline
\end{tabular}

$\mathrm{UU}$, the most users; OU, no users; PP, the most passers-by; OP, no passers-by.

The centre of Krakow is a populous mixed-use neighbourhood with potential for social inclusion and functional diversity, except for the gentrified Old Town. The city centre is characterized by a high concentration of businesses and workplaces, as well as being home to universities and schools, which reduces the need for commuting between neighbourhoods. Although pedestrianisation is relatively high, the potential of some facilities has not been exploited at all. The MOS constitutes an exception, as apparently Krakow residents treat it as an iconic place. The mapping showed groups of young people coming here to take photos, organize photo-shoots and small pandemic gatherings, sitting and drinking both at café tables and on benches (also as part of hen and stag parties).

\subsection{Method C}

Figure 8 presents the results of the questionnaire survey. Overall, the MOS, Cricoteka and the Manggha Centre were rated highest, while the Krakow Opera was rated worst (except for the question about pedestrian access and the recollection of the appearance of the building), scoring below zero in four categories. Respondents commented negatively on the appearance of the surroundings of the building, their desire to spend time there, the amount of greenery around it and their perception of the size of the space. The results indicate that the choice of the site location by municipal authorities is misguided. According to the respondents, the most characteristic building is the ICE Congress Centre (they remember it best), while the Jozef Czapski Pavilion is the least recognizable. This building is one of the newer ones and is therefore the least known.

The respondents' answers to questions whether they like the building and its surroundings, whether they would like to go inside when passing by and spend time in its surroundings, form a coherent whole. The MOS was rated best in these categories, followed by Cricoteka and the Manggha Centre with the Far East Gallery, while the Krakow Opera and Auditorium Maximum were rated worst. The differential curves at these venues look interesting. In all cases, except for the Wyspianski Pavilion, respondents liked the building itself more than its surroundings. This difference is most pronounced in the case of ICE and the Krakow Opera, which may be related to the heavy traffic and high noise levels in the surroundings. The Wyspianski Pavilion, on the other hand, received significantly higher scores for its surroundings, which is most likely due to its location in the historic fabric of the city centre along the Royal Road. The respondents indicated less frequently than in the question about aesthetics that they felt like entering the building when passing by. They perceive the building and its surroundings more as an aesthetic site than as a 
place for any activity, which may be due to the functional programme or the rather closed form of the building.

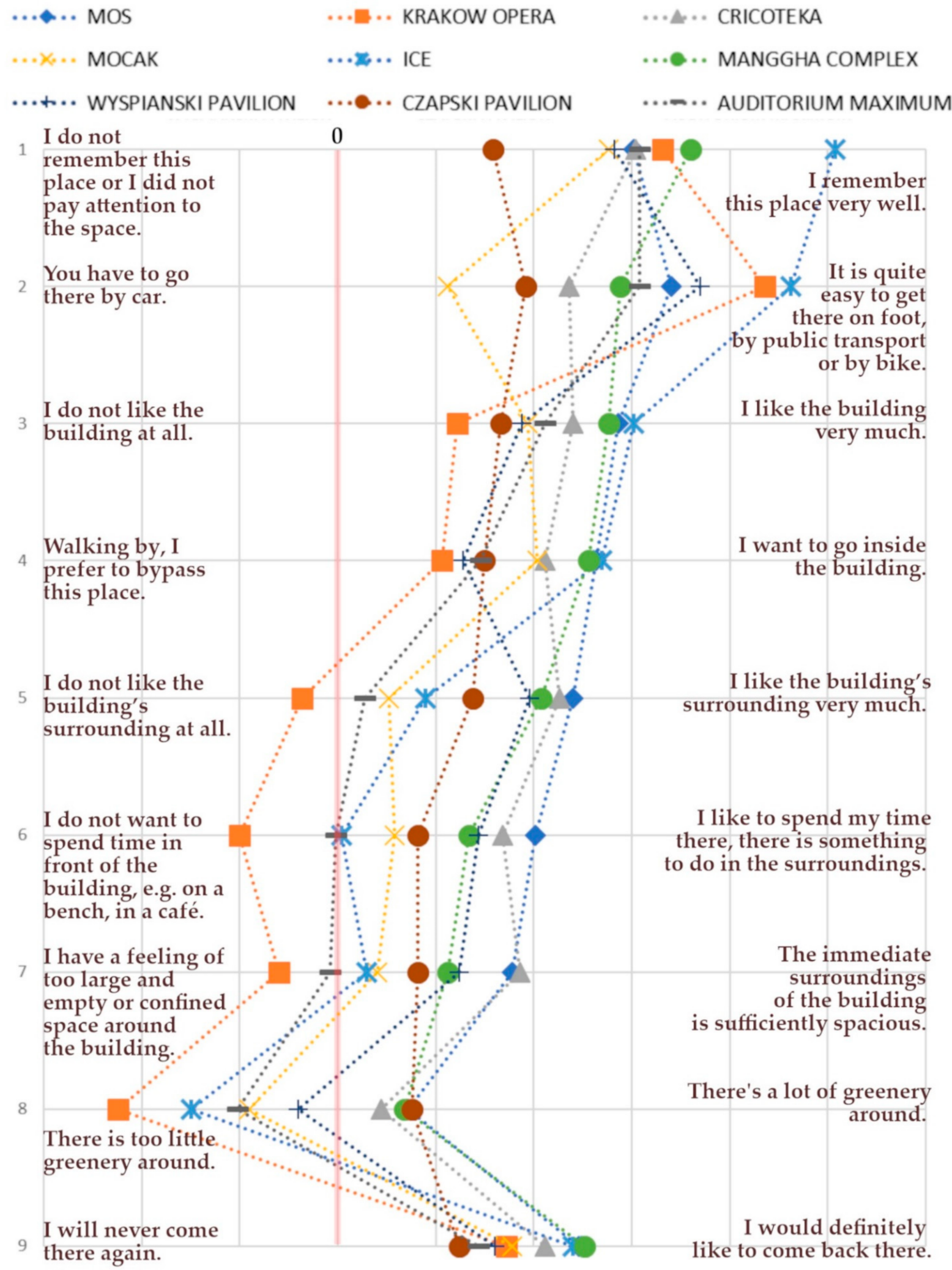

Figure 8. The survey results. The detailed survey results are available in Supplementary Material S2. 
In all cases, except for MOCAK, respondents liked the building more than they wanted to go inside and liked the surroundings more than they thought that there was anything to do there. The answers to the last two questions overlap in the case of MOCAK. In turn, respondents indicated that they did not feel like spending time actively at the Krakow Opera, ICE and Auditorium Maximum, which is consistent with the results of Method B.

The results regarding access by public transport, on foot and by bicycle show different patterns - the respondents rank the vehicle and walking access to the Krakow Opera and ICE as the best, and to MOCAK and the Jozef Czapski Pavilion as the worst. For those venues, they most often choose the option of having to commute by car. The highest-rated facilities are actually located near bus and tram stops with a large number of lines. Access to green spaces was rated the worst of all issues by respondents, who stated that there were too few green spaces around the facilities studied. This is where the semantic differential curves slump, reaching the lowest function value in all cases. The highest scores here were given to four facilities located close to each other: the Manggha Centre, the MOS, Cricoteka and the Jozef Czapski Pavilion. The remaining venues received total scores below zero.

The perception of the size of the space around the building was rated slightly better than the amount of greenery. The results were worse than in the question on greenery only in the Jozef Czapski Pavilion. The respondents most probably regard this space as too cramped. In turn, the two worst scores regarding this question were given to the Krakow Opera and ICE which are actually located in a sparser urban fabric, with wide arterial roads. One can guess that the respondents were pointing to the lack of enclosed space delineating the venue, as seen in Lewicka's assessment [56].

When summarising the correlations between the responses, a very high correlation can be seen between the responses to questions on whether the respondents like the building and are willing to go inside (Q3 and 4: 0.93) and whether they like the surroundings and want to spend time there (Q5 and 6: 0.96). The willingness to return to a place correlates with the willingness to go inside a building (Q4 and 9: 0.87) and with the question on whether respondents like the building (Q3 and 9: 0.82). The above correlations can be considered as a validation of the reliability of completing the questionnaires. The questions were formulated in such a way that the author expected them to appear.

The answers to the question on how the size of the space around a building is perceived correlate with the answers to the questions on whether the surroundings of the building are liked (Q5 and 7: 0.97) and whether respondents feel like spending time there (Q6 and 7: 0.98). The answer to the question about whether there is enough greenery around the building correlates most strongly with opinions on whether the respondents enjoy spending time around the building (Q6 and 8: 0.88).

Table 5 shows all correlations between responses to the questions.

Table 5. Correlations between the survey answers.

\begin{tabular}{|c|c|c|c|c|c|c|c|c|c|}
\hline Q NO. & 1 & 2 & 3 & 4 & 5 & 6 & 7 & 8 & 9 \\
\hline 1 & 1.00 & 0.67 & 0.59 & 0.52 & -0.13 & -0.27 & -0.21 & -0.47 & 0.67 \\
\hline 2 & & 1.00 & 0.17 & -0.01 & -0.16 & -0.35 & -0.27 & -0.49 & 0.29 \\
\hline 3 & & & 1.00 & 0.93 & 0.57 & 0.50 & 0.51 & 0.37 & 0.82 \\
\hline 4 & & & & 1.00 & 0.51 & 0.47 & 0.48 & 0.39 & 0.87 \\
\hline 5 & & & & & 1.00 & 0.96 & 0.97 & 0.47 & 0.47 \\
\hline 6 & & & & & & 1.00 & 0.98 & 0.88 & 0.37 \\
\hline 7 & & & & & & & 1.00 & 0.20 & 0.41 \\
\hline 8 & & & & & & & & 1.00 & 0.20 \\
\hline 9 & & & & & & & & & 1.00 \\
\hline
\end{tabular}

\subsection{Correlations}

Table 6 shows the correlation between the responses to the questionnaire survey and Method A. The strongest correlated factors were the responses to the question on the amount of greenery and the aesthetic perception of the building (0.93). The biophilia of the 
city residents is clearly evident here. A slightly lower correlation coefficient was obtained between aesthetics (GOAL 4) and the questions on the perception of the surroundings and the willingness to spend time there as well as the perception of the size of the space around the building (0.78-0.85) and between the answer to the question on the amount of greenery and environmental solutions (GOAL 3: 0.79).

Table 6. Correlations between the survey and on-site analysis results (methods A and C).

\begin{tabular}{ccccccccccc}
\hline Q NO. & $\mathbf{1}$ & $\mathbf{2}$ & $\mathbf{3}$ & $\mathbf{4}$ & $\mathbf{5}$ & $\mathbf{6}$ & $\mathbf{7}$ & $\mathbf{8}$ & $\mathbf{9}$ \\
\hline GOAL 1 & 0.46 & 0.36 & 0.56 & 0.46 & 0.61 & 0.52 & 0.60 & 0.17 & 0.55 \\
GOAL 2 & 0.17 & -0.04 & 0.75 & 0.73 & 0.76 & 0.75 & 0.75 & 0.56 & 0.53 \\
GOAL 3 & 0.09 & -0.21 & 0.70 & 0.71 & 0.85 & 0.75 & 0.80 & 0.79 & 0.56 \\
GOAL 4 & -0.64 & -0.47 & 0.18 & 0.18 & 0.78 & 0.85 & 0.79 & 0.93 & 0.01 \\
GOAL 5 & -0.09 & -0.45 & 0.38 & 0.43 & 0.35 & 0.41 & 0.50 & 0.39 & 0.13 \\
\hline
\end{tabular}

The issue of walking, cycling and public transport access (GOAL 1) was not very strongly correlated with responses to any survey question (maximum 0.61), nor was social capacity (GOAL 5). In contrast, responses to questions on whether respondents liked the building and its surroundings, their willingness to go inside and spend time around the building as well as activities in and around the building (GOAL 2) and environmental issues (GOAL 3 ) were very strongly correlated (0.7-0.85). This confirms the potential of gathering users for both necessary and optional activities by filling the space with diverse functions and paying attention to environmental solutions.

The correlations between the answers to the survey questions were checked using method B (see Table 7). There is a correlation between the number of users of the space and the total number of users and pedestrians in all responses concerning the surroundings of the buildings (questions 5-8). The strongest correlations were the positive responses given by the respondents on whether there is enough space around the buildings and enough greenery in the surrounding area (0.6-0.69). Again, these correlations indicate biophilia.

Table 7. Correlations between the survey and behavioural mapping (methods B and C).

\begin{tabular}{ccc}
\hline Question Number & Users & Users and Passers \\
\hline 1 & -0.13 & 0.04 \\
\hline 2 & -0.50 & -0.51 \\
\hline 3 & 0.33 & 0.45 \\
\hline 4 & 0.46 & 0.64 \\
\hline 5 & 0.59 & 0.52 \\
\hline 6 & 0.57 & 0.55 \\
\hline 7 & 0.60 & 0.57 \\
\hline 8 & 0.69 & 0.53 \\
\hline 9 & 0.44 & 0.61 \\
\hline
\end{tabular}

\section{Discussion and Conclusions}

The case study evaluation of the spatial-functional potential of cultural buildings in the historic urban fabric to achieve sustainable development, based on selected buildings in Krakow, demonstrated a relationship between the attributes of sustainable development and the 'popularity of buildings'-positive perception and the intensity in using the space around the buildings.

The most strongly correlated features relate to the presence of green areas and blue infrastructure and the service potential in terms of auxiliary functions connected to the furnishing of the space rather than the cultural mission of the buildings-places to eat and drink (café, bistro, restaurant, etc.), canopies, seating areas (including non-standard ones, 
i.e., walls, steps, railings) and the presence of art in the public space. These elements appear to fit into the individual genius loci of a place, conditioning its positive perception. The issues of activities available in the surroundings, denoting the surrounding buildings and access by public transport (meeting 11.2 SDG target quite well) turned out to be less important. This may be due to the comparably good accessibility of all sites, which paradoxically limited the study by the lack of contrasting cases and the comparably compact pattern of development, dense street network and natural surveillance during daytime. While affecting the walkability of the places, the less visible correlations between the morphology and aesthetics of the buildings and their perception indicate only the negatively perceived cases, without clearly differentiating the best ones.

The research shows that the residents notice and appreciate principles of urban ecology employed in buildings. If a building has more auxiliary functions and a better connection to green areas, it is more likely to remain functional in the city during the lockdown period, even when its main function is temporarily suspended and the number of tourists is significantly reduced. This affects the flexibility of the space in certain contingencies. Urban space becomes more resilient to both biological and human-induced disasters. It must be noted, however, that the environmental solutions implemented in Krakow are limited to the simplest ones, incorporating nature in the built environment, and thus reducing the UHI effect. No renewable energy and zero waste concepts are employed in the buildings. Hence, the implementation of 11.6 SDG target has been progressing very slowly, while that of 11.7 SDG target has been faster. That leads to the bitter conclusion that creating open active green spaces owned by a city or a province poses a problem in the centre of Europe that is striving to turn entire districts into zero-energy ones [63].

Specific site conditions (e.g., small plots, spatial chaos, no parking spaces, dense urban structure) combined with historic cultural heritage of Krakow have resulted in a new model of cultural buildings, in which designers either preserve the existing plots, historic buildings and their remnants, or use traces of the past, such as the geometry of roofs, materials, colours, details and proportions. Due to irregular shapes of the plots and various elements of the spatial context, adequate architectural forms had to be found for the new buildings. This balance of historic heritage with new forms and functions targets 11.4 SDG well.

The research showed that the city which is 'learning' to be an inclusive, citizen-friendly space-and Krakow seems to be doing so-introduces mixed-use buildings and public spaces connected with green areas. The architecture under study has been evolving from pursuing the 'wow' factor through more hybrid structures whose architects cared more for genius loci and inclusive space that can be used by the citizens for various purposes (sitting, talking, observing and participating in the social theatre, walking with children and dogs, cycling, etc.) to small lapidary forms inscribed in the context but without 'pretending' to be structures from the past, 'donning' a historical costume. Such contextualisation has the potential to link the spaces around buildings with the municipal system of inclusive public spaces, hitherto untapped in Krakow as shown by the mapping. According to research by the Center for Active Design, exploiting this potential of the so-called 'third places' in the city would promote social interaction and raise the level of civic trust [57].

The Krakow case study also revealed the low presence of culture in the public space. The cultural institutions do not use the outdoor space in the city for exhibitions, lectures, etc. This deficiency has been confirmed by the results of the reports commissioned by the city hall $[46,64]$. Their authors postulate the use of parks, green areas and the introduction of contemporary art into the public space. Such a measure would also be consistent with the Streets for Pandemic Response and Recovery strategy, in which NACTO envisaged a new purpose for streets during the COVID-19 pandemic, namely gatherings, events, play, school, etc [65]. Exhibitions, workshops, cinema screenings and other cultural events would fit well into the catalogue of activities, preventing the physical alienation of the community. At the same time, the closure of museums and other cultural venues in a 
forced semi-lockdown during the pandemic would not derail the continued use of the buildings regardless of cultural offer, thus lowering stress levels.

The postulate to incorporate cultural buildings into the public space system is also connected with the need to deagglomerate the municipal cultural offer and strengthen the culture-forming potential of districts located further from the central Old Town [46]. The sites analysed in the research contribute to this scheme, but they fail to expand the scope of their activities. The study commissioned by the Malopolska Voivodeship Office has illustrated the positive impact of the new facilities on the city space, as well as the prestige of the district and the surrounding economy [46]. At the same time, it is desirable to support the natural processes in which creative hubs emerge around such facilities as Cricoteka and MOCAK that are built in post-industrial districts [46]. The report from the study on Krakow's cultural sector includes a proposal to counteract the gentrification of Zabłocie and Podgórze districts as this process is stifling gatherings of Krakow's bohemians around these cultural venues. Unfortunately, the analysis of land prices and the functions of new investments shows that the protection of these areas is unsuccessful as more and more expensive housing developments fill the post-industrial areas, supplanting semi-formal artistic users [46].

By means of behavioural mapping, Mantey has shown that the greatest influence on the use value of a given space is its diversity [62]. The heterogeneity of users contributes to integration, and the more groups a given space is designed for, the more people in it. The study presented here found deficiencies (or rather lack of such elements) in the design of spaces for different age groups. Thus, one may speculate that the spaces developed with facilities for seniors and children would generate more traffic. There is also a correlation with pedestrian traffic - the more traffic around an area (busier point in the city), the higher the activity level of the space. The diversity of the space increases its use value.

The study had limitations, due to time limits, data collection during the pandemic and subjectivity of the observations. However, to counteract the arbitrariness of the sample, the author examined all contemporary cultural buildings located in the historic zones of Krakow as cases. They were built in the 1990s and later. Earlier buildings of this type were constructed up to the 1930s in Krakow [66].

The author supplemented the subjective partial observational results in method A with quantitative data and then verified them by means of quantitative data from methods $B$ and $C$. These methods also had their limitations. The behavioural mapping conducted before the complete closure of museums during the second wave of the covid pandemic in Poland could not be repeated for time reasons. The respondents' particulars in the survey indicated a high interest in the questionnaire among people whose profession is related to art (45 out of 173 responses), people aged 18-26 (66 responses) and those with higher education (96 responses). Such a profile of respondents does not correspond to the demographics of Krakow's residents, yet it is similar to the profile of people who positively assess the impact of cultural institutions on the quality of life of the local community (the impact of infrastructure projects). It may therefore be assumed that those individuals were interested in completing the questionnaire.

The questionnaire survey yielded 173 responses, which, with a population of 771,069 people in Krakow in 2019 [67], a fraction size of 0.5 and a confidence level of 95\%, resulted in a statistical error of $7 \%$. Due to pandemic constraints, it is hardly possible to collect a larger survey group at the moment. Further research, e.g., using the PAPI (Pen-and-Paper Personal Interview) method, would potentially allow for more extensive results, but it would require direct contact with larger groups of Krakow residents.

Another limitation of the behavioural mapping method was the lack of comparison of the concentration of people in other places in Krakow-the less and more familiar public spaces with different functions and amenities. Comparing the results of the selected cases with other spaces would provide a background for determining their level of use and enable the identification of model sites with greater potential. Such a study requires more time and human resources and could be the subject matter of a separate paper, as well 
as serving as the monitoring of the places at different times of the year and the changing reality of the pandemic.

Thus, one must take into account the limitations of the research when analysing its results. Time constraints and lack of direct contact during the pandemic lockdown precluded continuation of the research. In turn, if continued after the return of increased tourist traffic, it would not show the potential of the buildings to function in a public space geared towards Krakow's residents.

Urban governance, leadership and best practice were not analysed in the study either. The Center for Active Design and the Gehl Institute point to the positive role of participatory design in public spaces [57,61]. Requiring separate research methods, these issues need further analysis that would answer the question of the extent to which the city authorities implement their professed care for environmental issues and social participation in governing. A preliminary examination of the topic suggests that they do so, to a certain extent. Some degree of social engagement of experts in the development of cultural buildings in Krakow is also noticeable. The majority of the designs discussed here were selected by means of a call for proposals, i.e., expert assessments.

The main message of the paper is to indicate how important it is for the creation of cultural spaces in the city to develop a range of their activities, linked to the surrounding public space and green areas. The relationship with greenery is central to this issue, especially when it replaces different technologies employed in a building to counteract climate change. Activating cultural spaces in the city and linking them to sustainability goals is especially important in a post-pandemic reality when the number of tourists is decreasing and the gentrified districts need to regain their former vibrancy.

Supplementary Materials: The following are available online at https:/ / www.mdpi.com/article/10 $.3390 /$ su13116126/s1.

Funding: This research received no external funding.

Institutional Review Board Statement: Not applicable.

Informed Consent Statement: Not applicable.

Data Availability Statement: The data presented in this study are available in [Supplementary material] and [repository name e.g., FigShare] at [doi], reference number [reference number]. Some Data are available in a publicly accessible repositories of the different branches of the Office of the City of Cracow and the General Statistics Office. They are all showed in References section.

Conflicts of Interest: The authors declare no conflict of interest.

\section{References}

1. Al-Saeed, Y.W.; Ahmed, A. Evaluating Design Strategies for Nearly Zero Energy Buildings in the Middle East and North Africa Regions. Designs 2018, 2, 35. [CrossRef]

2. D'Agostino, D.; Zangheri, P.; Castellazzi, L. Towards Nearly Zero Energy Buildings in Europe: A Focus on Retrofit in NonResidential Buildings. Energies 2017, 10, 117. [CrossRef]

3. Strategies for a Nearly Zero-Energy Building Market Transition in the European Union. Available online: https://zebra2020.eu/ publications/strategies-for-a-nearly-zero-energy-building-market-transition-in-the-european-union/ (accessed on 11 April 2021).

4. IEA. Coal Information: Overview, IEA, Paris. Available online: https://www.iea.org/reports/coal-information-overview (accessed on 11 April 2021).

5. Eurostat Coal Production and Consumption Statistics-Statistics Explained (europa.eu). Available online: https://ec.europa.eu/ eurostat/statistics-explained/index.php?title=Coal_production_and_consumption_statistics. (accessed on 10 April 2021).

6. Coal 2019, IEA, Paris. Available online: https:/ / www.iea.org/reports/coal-2019 (accessed on 10 April 2021).

7. Eurostat, Municipal Waste Statistics. Available online: https://ec.europa.eu/eurostat/statistics-explained/index.php/ Municipal_waste_statistics-Municipal_waste_treatment (accessed on 12 April 2021).

8. Mioduszewski, W.; Okruszko, T.; Kardel, J.; Fehér, J.; Gáspár, J.; Tamas, J.; Mosný, V.; Muller, R.; Istenič, D.; Potokar, A. Natural Small Water Retention Measures: Combining Drought Mitigation, Flood Protection, and Biodiversity Conservation-Guidelines; Global Water Partnership Central and Eastern Europe: Bratislavia, Slovakia, 2015. Available online: https://www.gwp.org/en/gwp-cee/ (accessed on 25 May 2021). 
9. Pope, P.; Annandale, D.; Morrison-Saunders, A. Conceptualising sustainability assessment. Environ. Impact Assess. Rev. 2004, 6, 595-616. [CrossRef]

10. Troi, A. Historic buildings and city centres-The potential impact of conservation compatible energy refurbishment on climate protection and living conditions. In Proceedings of the Conference Energy Management in Cultural Heritage, Dubrovnik, Croatia, 6-8 April 2011.

11. Oke, T. Towards Better Scientific Communication in Urban Climate. Theor. Appl. Climatol. 2006, 84, 179-190. [CrossRef]

12. Kumar, P.; Druckman, A.; Gallagher, J.; Gatersleben, B.; Allison, S.; Eisenman, T.S.; Hoang, U.; Hama, S.; Tiwari, A.; Sharma, A.; et al. The nexus between air pollution, green infrastructure and human health. Environ. Int. 2019, 133, 105181. [CrossRef]

13. Ramos, J.S.; Domínguez, S.Á.; Moreno, M.P.; Delgado, M.G.; Rodríguez, L.R.; Ríos, J.A.T. Design of the Refurbishment of Historic Buildings with a Cost-Optimal Methodology: A Case Study. Appl. Sci. 2019, 9, 3104. [CrossRef]

14. London, F. Healthy Place Making, 1st ed.; RIBA Publishing: London, UK, 2020; ISBN 978-1-85946-883-8.

15. Cristiano, S.; Gonella, F. 'Kill Venice': A systems thinking conceptualisation of urban life, economy, and resilience in tourist cities. Hum. Soc. Sci. Commun. 2020, 7, 143. [CrossRef]

16. Krakowska Kultura w Czasie Epidemii COVID-19. Available online: www.krakow.pl (accessed on 20 April 2021).

17. Borkowski, K.; Grabiński, T.; Seweryn, R.; Rotter, L.; Mazanek, L.; Grabińska, E. Ruch Turystyczny w Krakowie w 2019 roku, 1 st ed.; Małopolska Organizacja Turystyczna: Kraków, Poland, 2020.

18. Ruch Turystyczny w Krakowie. UM Kraków. Available online: www.bip.krakow.pl (accessed on 15 March 2021).

19. Office of the City of Krakow (UMK). Strategia Rozwoju Krakowa "Tu Chce żyć. Kraków 2030". Available online: https: //www.bip.krakow.pl/?dok_id=94892 (accessed on 27 April 2021).

20. Roggema, R. The Future of Sustainable Urbanism: Society-Based, Complexity-Led, and Landscape-Driven. Sustainability 2017, 9 , 1442. [CrossRef]

21. Heymans, A.; Breadsell, J.; Morrison, G.M.; Byrne, J.J.; Eon, C. Ecological Urban Planning and Design: A Systematic Literature Review. Sustainability 2019, 11, 3723. [CrossRef]

22. Jagodzińska, K.; Sanetra-Szeliga, J.; Purchla, J.; Van Balen, K.; Thys, C.; Vandesande, A.; Van der Auwera, S. Cultural Heritage Counts for Europe: Full Report; International Cultural Centre: Kraków, Poland. Available online: http://blogs.encatc.org/ culturalheritagecountsforeurope/ (accessed on 18 May 2021).

23. Petti, L.; Trillo, C.; Makore, B.N. Cultural Heritage and Sustainable Development Targets: A Possible Harmonisation? Insights from the European Perspective. Sustainability 2020, 12, 926. [CrossRef]

24. Dessein, J.; Soini, K.; Fairclough, G.; Horlings, L. Culture in, for and as Sustainable Development; Conclusions from the COST ACTION IS1007 Investigating Cultural Sustainability 2015. Available online: https:/ / www.cost.eu (accessed on 15 April 2021).

25. Soini, K.; Dessein, J. Culture-Sustainability Relation: Towards a Conceptual Framework. Sustainability 2016, 8, 167. [CrossRef]

26. Cushing, D.F.; Miller, E. Creating Great Places: Evidence-Based Urban Design for Health and Wellbeing, 1st ed.; Routledge: New York, NY, USA, 2020; ISBN 9780429289637.

27. Stylianou-Lambert, T.; Boukas, N.; Christodoulou-Yerali, M. Museums and cultural sustainability: Stakeholders, forces, and cultural policies. Int. J. Cult. Policy 2014, 20, 566-587. [CrossRef]

28. McGhie, H.A. Museums and the Sustainable Development Goals: A How-To Guide for Museums, Galleries, the Cultural Sector and Their Partners; Curating Tomorrow: Liverpool, UK, 2019. Available online: www.curatingtomorrow.co.uk (accessed on 13 April 2021).

29. ICOMOS 2016. Cultural Heritage, the UN Sustainable Development Goals, and the New Urban Agenda; ICOMOS Concept Note for the United Nations Agenda 2030 and the Third United Nations. Available online: www.icomos.org (accessed on 5 March 2021).

30. Baki Nalcioğlu, Ü.Z.S. The cultural aspect of sustainability in museums. Milli Folk. 2021, 129, $124-135$.

31. Honey-Rosés, J.; Anguelovski, I.; Bohigas, J.; Chireh, V.; Daher, C.; Konijnendijk van den Bosch, C.; Litt, J.; Mawani, V.; McCall, M.; Orellana, A.; et al. The Impact of COVID-19 on Public Space: A Review of the Emerging Questions. Cities Health 2020, 1-17. [CrossRef]

32. Streets for Pandemic Response \& Recovery I 09/24/2020. Available online: https://nacto.org/publication/streets-for-pandemicresponse-recovery / (accessed on 7 March 2021).

33. Gehl, J. Cities for People, 1st ed.; Island Press: Washington, DC, USA, 2010; ISBN 9781597265737.

34. Matthew Carmona, for the Place Alliance, Place Value, and the Ladder of Place Quality. Available online: http:/ / placealliance. org.uk/research/place-value/ (accessed on 2 March 2021).

35. Koncepcja Przestrzennego Zagospodarowania Kraju 2030. Available online: https://miir.bip.gov.pl/strategie-rozwoj-regionalny/ 17847_strategie.html (accessed on 15 March 2021).

36. Zachariasz, A. Development of the System of the Green Areas of Krakow from The Nineteenth Century to The Present, In The Context of Model Solutions. IOP Conf. Ser. Mater. Sci. Eng. 2019, 471, 112097. [CrossRef]

37. Telega, A.; Telega, I.; Bieda, A. Measuring Walkability with GIS-Methods Overview and New Approach Proposal. Sustainability 2021, 13, 1883. [CrossRef]

38. Jarosińska, E.; Gołda, K. Increasing Natural Retention-Remedy for Current Climate Change in Urban Area. Urban Clim. 2020, 34, 100695. [CrossRef]

39. Gyurkovich, M.; Gyurkovich, J. New Housing Complexes in Post-Industrial Areas in City Centres in Poland Versus Cultural and Natural Heritage Protection-With a Particular Focus on Cracow. Sustainability 2021, 13, 418. [CrossRef] 
40. Dudzic-Gyurkovich, K. Urban Development and Population Pressure: The Case of Młynówka Królewska Park in Krakow, Poland. Sustainability 2021, 13, 1116. [CrossRef]

41. Porębska, A.; Godyń, I.; Radzicki, K.; Nachlik, E.; Rizzi, P. Built Heritage, Sustainable Development, and Natural Hazards: Flood Protection and UNESCO World Heritage Site Protection Strategies in Krakow, Poland. Sustainability 2019, 11, 4886. [CrossRef]

42. Kwartnik-Pruc, A.; Trembecka, A. Public Green Space Policy Implementation: A Case Study of Krakow, Poland. Sustainability 2021, 13, 538. [CrossRef]

43. Główny Urząd Statystyczny. Statistics Poland. Kultura w 2019 r. Culture in 2019. Available online: Stat.gov.pl (accessed on 18 March 2021).

44. Jagodzińska, K. Czas Muzeów w Europie Środkowej. Muzea i Centra Sztuki Wspótczesnej (1989-2014), 1st ed.; Międzynarodowe Centrum Kultury: Kraków, Poland, 2014; ISBN 9788363463229.

45. Gyurkovich, M. Polskie Przestrzenie Kultury. Wybrane Zagadnienia, 1st ed.; Wydawnictwo Politechniki Krakowskiej: Kraków, Poland, 2019; ISBN 978-83-65991-33-1.

46. Rudolf, A.; Marciniak, M.; Pieniążek, W.; Chojecki, J.; Penszko, P.; Jońca, A. Raport Końcowy z Badania Sektora Kultury KRAKOWSKA Kultura-Stan Obecny i Perspektywy Rozwoju; Agrotec Polska: Warszawa, Poland, 2015. Available online: http:/ / krakow.pl (accessed on 5 April 2021).

47. Biuro Badań Społecznych Question Mark. Wptyw Projektów Infrastrukturalnych z Zakresu Kultury Zrealizowanych w Małopolsce na Otoczenie Społeczno-Gospodarcze. Raport z Badań; Małopolskie Obserwatorium Rozwoju Regionalnego, Departament Polityki Regionalnej: Kraków, Poland, 2018. Available online: https://www.obserwatorium.malopolska.pl/ (accessed on 15 April 2021).

48. UNESCO Worls Heritage Centre. Historic Centre of Kraków. Available online: Whc.unesco.org (accessed on 5 October 2020).

49. Creswell, J. Research Design: Qualitative, Quantitative and Mixed Methods Approaches, 3rd ed.; SAGE Publications: New York, NY, USA, 2011; ISBN 101412965578.

50. Silverman, D. Doing Qualitative Research. A Practical Handbook, 2nd ed.; SAGE Publications: New York, NY, USA, 2005; ISBN 10 1412901960.

51. Gehl, J. Life between Buildings: Using Public Space, 6th ed.; Island Press: Washington, DC, USA, 2011; ISBN 978-1-59726-827-1.

52. Kesik, O.; Demirci, A.; Karaburun, A. Analysis of Pavements for Disabled Pedestrians in Metropolitan Cities, 1st ed.; Lambert Academic Publishing: Chisinau, Moldova, 2012; ISBN 9783846588888.

53. National Association of City Transportation Officials. Urban Bikeway Design Guide, 1st ed.; Island Press: Washington, DC, USA, 2013; ISBN 9781610914949.

54. Lehmann, S. Green Urbanism: Formulating a Series of Holistic Principles. S.A.P.I.En.S 2010, 3, 1-10. Available online: http: / /journals.openedition.org/sapiens/1057 (accessed on 6 October 2020).

55. Elliott, H.; Eon, C.; Breadsell, J.K. Improving City Vitality through Urban Heat Reduction with Green Infrastructure and Design Solutions: A Systematic Literature Review. Buildings 2020, 10, 219. [CrossRef]

56. United States Environmental Protection Agency. EPA Heat Islands Cooling Strategies. Available online: https://www.epa.gov/ heatislands/heat-island-cooling-strategies (accessed on 2 April 2021).

57. Center for Active Design. Assembly: Civic Design Guidelines. Available online: https://centerforactivedesign.org/assembly (accessed on 14 March 2021).

58. Project for Public Space. What Makes a Successful Place? Available online: https://www.pps.org/article/grplacefeat (accessed on 14 March 2021).

59. Lewicka, M. Psychologia Miejsca, 1st ed.; Scholar: Warszawa, Polska, 2012; ISBN 978-83-7378-476-7.

60. Lofland, L. The Public Realm. Exploring the City's Quintessential Social Territory, 1st ed.; Aldine de Gruyter: New York, NY, USA, 1998; ISBN 0-202-30607-0.

61. Gehl Institute. Inclusive Healthy Places. A Guide to Inclusion \& Health in Public Space: Learning Globally to Transform Locally. Available online: https:/ / gehlinstitute.org (accessed on 23 February 2021).

62. Mantey. Wzorzec Miejskiej Przestrzeni Publicznej w Konfrontacji z Podmiejska Rzeczywistością. Przykład Podwarszawskich Suburbiów, 1st ed.; Wydawnictwo Uniwersytetu Warszawskiego: Warszawa, Poland, 2019; ISBN 978-83-235-3615-4.

63. Saheb, Y.; Shnapp, S.; Paci, D. From Nearly-Zero Energy Buildings to Net-Zero Energy Districts; Publications Office of the European Union: Luxembourg, 2019; ISBN 978-92-76-02915-1. [CrossRef]

64. Wydział Kultury i Dziedzictwa Narodowego Urzędu Miasta Krakowa. Program Rozwoju Kultury w Krakowie do roku 2030. Available online: www.krakow.pl (accessed on 5 March 2021).

65. National Association of City Transportation Officials. Available online: https://nacto.org/publication/streets-for-pandemicresponse-recovery/ (accessed on 20 April 2021).

66. Purchla, J.; Fabiański, M. Historia Architektury Krakowa w Zarysie, 1st ed.; Wydawnictwo Literackie: Krakow, Poland, 2001; ISBN 9788308031667.

67. Urząd Statystyczny w Krakowie. Statistical Office in Kraków. Available online: www.stat.gov.pl (accessed on 16 April 2021). 